\title{
Breast Cancer Risk Factors in Iran: A Systematic Review \& Meta-analysis
}

Amir Shamshirian ${ }^{1,11}$, Keyvan Heydari ${ }^{2,11}$, Zahra Shams ${ }^{3}$, Amir Reza Aref ${ }^{4}$, Danial Shamshirian ${ }^{5}$, Omid Reza Tamtaji ${ }^{6}$, Zatollah Asemi ${ }^{6}$, Hamed Mirzaei ${ }^{6}$, Neda Mohammadi ${ }^{7}$, Behdad Zibaee ${ }^{8}$, Keyvan Karimifar ${ }^{9}$, Bahman Zarandi ${ }^{10}$, Akbar Hedayatizadeh-Omran ${ }^{11}$, Reza Alizadeh-Navaei ${ }^{11^{*}}$

1. Department of Medical Laboratory Sciences, Student Research Committee, School of Allied Medical Science, Mazandaran University of Medical Sciences, Sari, Iran.

2. Student Research Committee, School of Medicine, Mazandaran University of Medical Sciences, Sari, Iran.

3. Cardiovascular Diseases Research Center, Department of Cardiology, Heshmat Hospital, School of Medicine, Guilan University of Medical Sciences, Rasht, Iran.

4. Belfer Center for Applied Cancer Science, Department of Medical Oncology, Dana-Farber Cancer Institute, Harvard Medical School, Boston, MA, USA.

5. Chronic Respiratory Diseases Research Center, National Research Institute of Tuberculosis and Lung Diseases (NRITLD), Shahid Beheshti University of Medical Sciences, Tehran, Iran.

6. Research Center for Biochemistry and Nutrition in Metabolic Diseases, Kashan University of Medical Sciences, Kashan, Iran.

7. Student Research Committee, Faculty of Pharmacy, Mazandaran University of Medical Sciences, Sari, Iran.

8. Student Research Committee, School of Medicine, Gonabad University of Medical Sciences, Gonabad, Iran.

9. Student Research committee, Mashhad University of Medical Sciences, Mashhad, Iran.

10. Student Research Committee, Iran University of Medical Sciences, Tehran, Iran.

11. Gastrointestinal Cancer Research Center, Mazandaran University of Medical Sciences, Sari, Iran.

Corresponding author:

Reza Alizadeh-Navaei; Gastrointestinal Cancer Research Center, Mazandaran University of Medical Sciences, Sari, Iran.

E-Mail: reza_nava@yahoo.com

Tel: +989111147563 


\begin{abstract}
:
To systematically investigate the epidemiology of breast cancer risk factors in Iran.

We performed a systematic search via PubMed, Scopus, Web of Science and Persian databases for identifying studies published on breast cancer risk factors up to March 2019. Meta-analyses were done for risk factors reported in more than one study. We calculated odds ratios (ORs) with corresponding 95\% confidence intervals (CIs) using a fixed/random-effects models.

Thirty-nine studies entered into the meta-analysis. Pooling of ORs showed a significant harmful effect for risk factors including family history (OR: 1.80, 95\%CI 1.47-2.12), HRT (OR: 5.48, 95\%CI 0.84-1.74), ER positive (OR: 1.87, 95\%CI 1.41-2.33), PR positive (OR: 1.84, 95\%CI 1.382.29), stress condition (OR: 2.67, 95\%CI 1.84-3.50), passive smokers (OR: 1.68, 95\%CI 1.342.03), full-term pregnancy at age 30 (OR: 3.41, 95\%CI 1.19-5.63), abortion (OR: 1.84, 95\%CI 1.35-2.33), sweets consumption (OR: 1.71, 95\%CI 1.32-2.11) and genotype Arg/Arg (crude OR: 1.59, 95\%CI 1.07-2.10), whereas a significant protective effect for late menarche (OR: 0.58, 95\%CI 0.32-0.83), nulliparity (OR: 0.68, 95\%CI 0.39-0.96), 13 to 24 months of breastfeeding (OR: 0.68, 95\%CI 0.46-0.90), daily exercise (OR: 0.59, 95\%CI 0.44-0.73) and vegetable consumption (crude OR: 0.28, 95\%CI 0.10-0.46).

This study suggest that factors such as family history, HRT, ER and PR positive status, stress condition, passive smokers, late full-term pregnancy, abortion, sweets consumption and genotype Arg/Arg might increase risk of breast cancer development, whereas late menarche, nulliparity, 1324 months breastfeeding, daily exercise and vegetable consumption had an inverse association with breast cancer development.
\end{abstract}

Keywords: Breast Tumor, Mammary Neoplasm, Breast Carcinoma, Meta-analysis, Population at Risk 


\section{Introduction:}

Breast cancer is one of the most common health concerns throughout the world [1-4], which includes $30 \%$ of female cancers [5,6]. It is also known as the second cause of death in developed countries and the third leading cause of death in less developed countries [7-9]. Surprisingly, approximately 502000 women die due to breast cancer annually [10]. According to the World Health Organization (WHO) prediction, up to 2.3 million women will be diagnosed for breast cancer by $2050[11,12]$.

In Iran, breast cancer has been identified as the most common cancer and also the fifth main cause of death among Iranian women $[13,4]$. The standardized incidence rate (ASR) is about 28 per 100,000 people, which has increased in recent years [14]. There are a variety of proven and controversial risk factors for breast cancer. The American Cancer Society has reported that only about a quarter of breast cancers are due to identified risk factors. These factors include aging, urban life, social class (upper-middle class), marital status (single), white race, history of ovarian cancer, early menstruation, post-menopause, history of breast cancer, history of breast fibrocystic, family history of breast, uterine and ovarian cancers, and history of radiation exposure. However, it seems that numerous factors have not yet identified [15].

According to the Iran, ageing, history of breast cancer, genetic modification, chest radiation therapy, diethylstilbestrol (DES) intervention, using hormonal replacement therapy (HRT), low levels of vitamin D, exposure to chemicals in cosmetics, diet, obesity [16], smoking [17], alcohol, fertility and hormonal factors, contraceptives, early menarche, late menopause, high age at first birth, absence of labor history, other malignancies such as ovarian and endometrial carcinoma, are all the most common reported risk factors for breast cancer $[18,19]$. 
Considering the incidence and prevalence of breast cancer, the high cost of treating the disease, and the fact that the disease affects young women who are productive in social and socioeconomic settings (about 35 years of age and older) and in case of early diagnosis of this disease (screening by mammography), this disease is one of the most potent cancers, the importance of which is more pronounced [20-23].

Despite the relatively high rate of breast cancer in the country and the importance of the associated risk factors with this malignancy, there is no nationwide study in this regard according to our knowledge. Hence, we aimed to undertake a systematic review and meta-analysis focus on the epidemiology of breast cancer risk factors in Iran. We hope our findings could provide a comprehensive report and to be useful for future studies. 


\section{Method:}

\section{Search Strategy}

We followed Preferred Reporting Items for Systematic Reviews and Meta-Analyses (PRISMA) guideline for study design, search protocol, screening and reporting. A systematic search was performed via international databases of PubMed, Scopus and Web of Science until 05 March 2019. Moreover, for finding Persian papers we used Google Scholar database and national databases of Scientific Information Database (SID), Iranmedex and Magiran. The search strategy included MeSH terms and free keywords as follows: ((Breast OR Mammary) AND (Cancer* OR Neoplasm* OR Tumor* OR Malignanc* OR Carcinoma*) AND ("Risk factor" OR "Risk factors" OR "Population at Risk" OR "Populations at Risk") AND AND Iran). Persian equivalent words were used for searching in national databases. There was no limitation about the date of publications in our search. Only human diagnostic studies on breast cancer were included.

\section{Criteria study selection}

Two group members (A.SH and K.HD) selected the papers independently and discussed to solve the disagreements. Studies met the following criteria included into meta-analysis: 1) studies were case-control or cohort; 2) studies included the risk factors of breast cancer patients in Iran; and 3) studies were considered the female breast cancer. Studies were excluded if they were: 1) conference abstracts, comments, letters, animal studies, reviews, case reports, ecological studies, cross-sectional studies, and in vitro studies; 2) duplicate publications; 3) insufficient for calculating of desired parameters, and 4) male breast cancer studies.

\section{Data extraction \& quality assessment}


Two researchers (Z.SH and K.HD) have independently evaluated the quality of studies and extracted data from included papers. The supervisor (R.AN) resolved any disagreements in this part. Data extraction checklist included the name of the first author, publication year, a region of study, number of patients, mean age, quantitative information of risk factors, clinicopathological features, and available correlations.

The Newcastle-Ottawa Scale (NOS) checklist was used to value the selected papers in relation to various aspects of the methodology and study process.

\section{Data analysis}

Statistical analysis was performed using STATA v.11 software. To assess the heterogeneities, we used the I-square $\left(I^{2}\right)$ test. According to the studies heterogeneity, we pooled results using a fixedeffects or random-effects model as appropriate for heterogeneity more or less than $50 \%$, respectively. 


\section{Results}

\section{Study selection process}

Our initial search through databases resulted in 562 papers. After excluding duplicated papers, remained papers screened using title and abstract. Finally, after eligibility assessment of 84 full texts, 41 studies entered into qualitative synthesis and finally, 39 studies entered into the metaanalysis. PRISMA flow diagram for the study selection process presented in Figure 1.

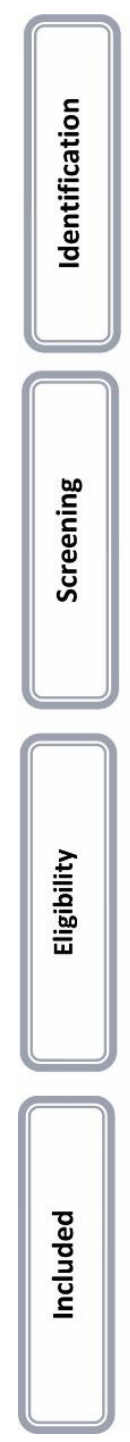

Records identified through database searching $(n=562)$ PubMed $=87$, Scopus $=250$, WoS $=133$, Persian database $=92$
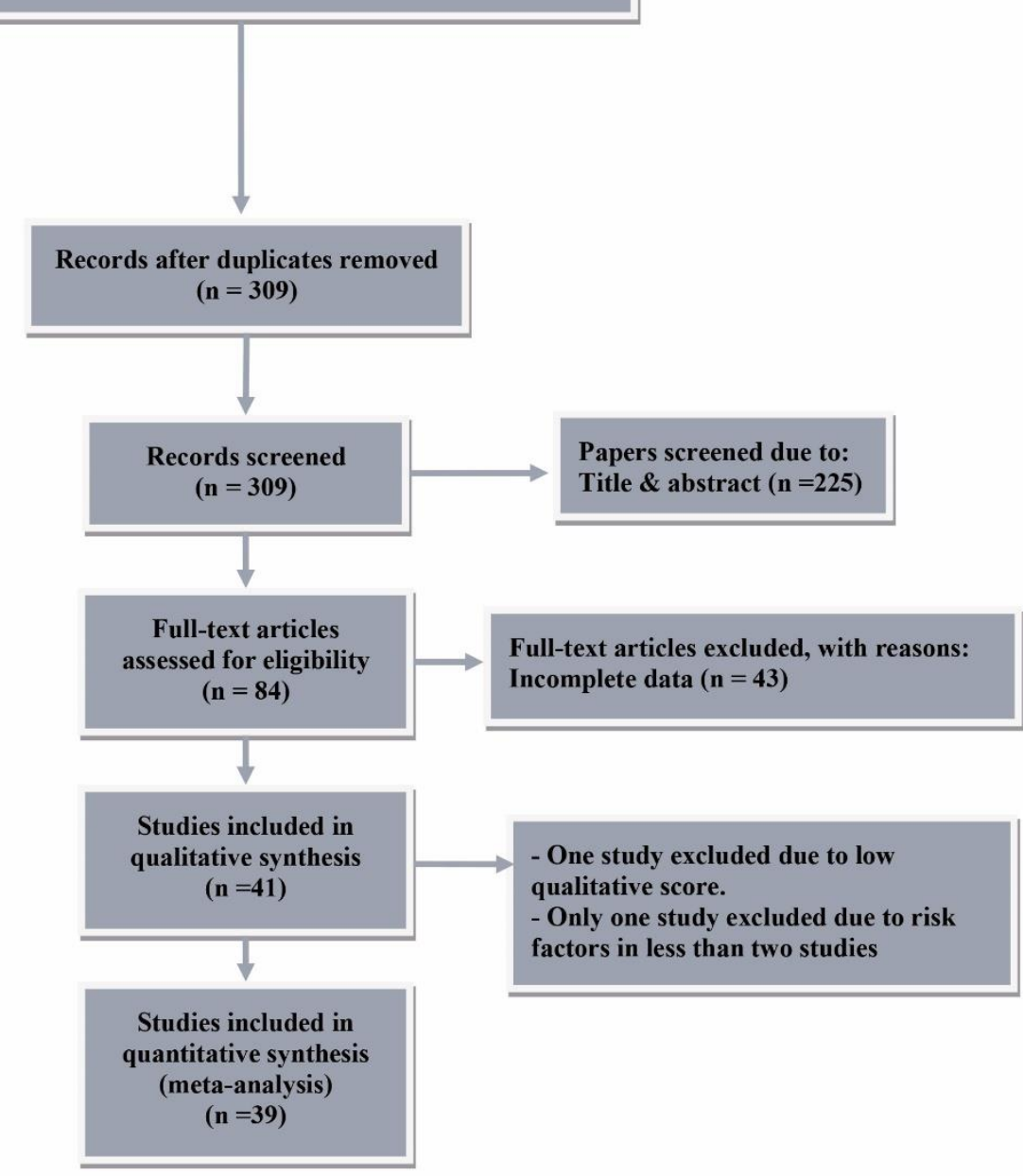

Fig. 1. PRISMA flowchart for study selection process 


\section{Study characteristics}

Out of 39 included studies, 35 studies were case-control and four of them were cross-sectional studies. The studies' sample size ranged from 93 to 25592 including 54347 participants. Nine studies were conducted in Tehran province, six in Fars, four in Mazandaran, four in Isfahan, three in East Azerbaijan, two in Guilan, two in Kermanshah, one in West Azerbaijan, one in Golestan, one in Yazd, one in Hormozgan, one in Khuzestan, and one in Razavi Khorasan. Moreover, one study was a joint study between Mazandaran and Guilan, and one study between Tehran and East Azerbaijan. Characteristics of studies entered into meta-analysis presented in Table 1. 
Table 1 Characteristics of studies entered into the meta-analysis

\begin{tabular}{|c|c|c|c|c|c|c|c|c|}
\hline Author (Year) & Design & Region C/P & $\begin{array}{l}\text { No. of Participants } \\
\text { (Case/Control) }\end{array}$ & $\begin{array}{c}\text { Total mean } \\
\text { age (SD) }\end{array}$ & $\begin{array}{c}\text { Case } \\
\text { Mean age } \\
\text { (SD) }\end{array}$ & $\begin{array}{c}\text { Control } \\
\text { Mean age } \\
\text { (SD) }\end{array}$ & Risk Factors & Adjusted by \\
\hline Ebrahimi et al. (2002) [24] & $\mathrm{CC}$ & Tehran C & $535(286 / 249)$ & - & $47.5(12.8)$ & 44.2(13.2) & $\begin{array}{l}\text { Age, Parity, FH, } \\
\text { OCP, MeS, MaS, } \\
\text { ES, Nulliparity, } \\
\text { AFFTP }\end{array}$ & - \\
\hline Pesaran et al. (2003) [25] & $\mathrm{CC}$ & Isfahan C & $352(176 / 176)$ & - & $49(11.3)$ & $47(11.4)$ & $\mathrm{FH}$ & - \\
\hline Montazeri et al. (2004) [26] & $\mathrm{CC}$ & Tehran C & $729(243 / 486)$ & - & $46.6(11.2)$ & $45.5(10.1)$ & $\begin{array}{c}\text { Age, FH, OCP, } \\
\text { MeS, MeAS, } \\
\text { MaS, ES, } \\
\text { Depression, } \\
\text { Hopelessness } \\
\text { Quality of life, } \\
\text { AFFTP, Anxiety, } \\
\text { psychiatric } \\
\text { medications }\end{array}$ & $\begin{array}{c}\text { MeAS, FH, } \\
\text { Depression and } \\
\text { Hopelessness }\end{array}$ \\
\hline
\end{tabular}




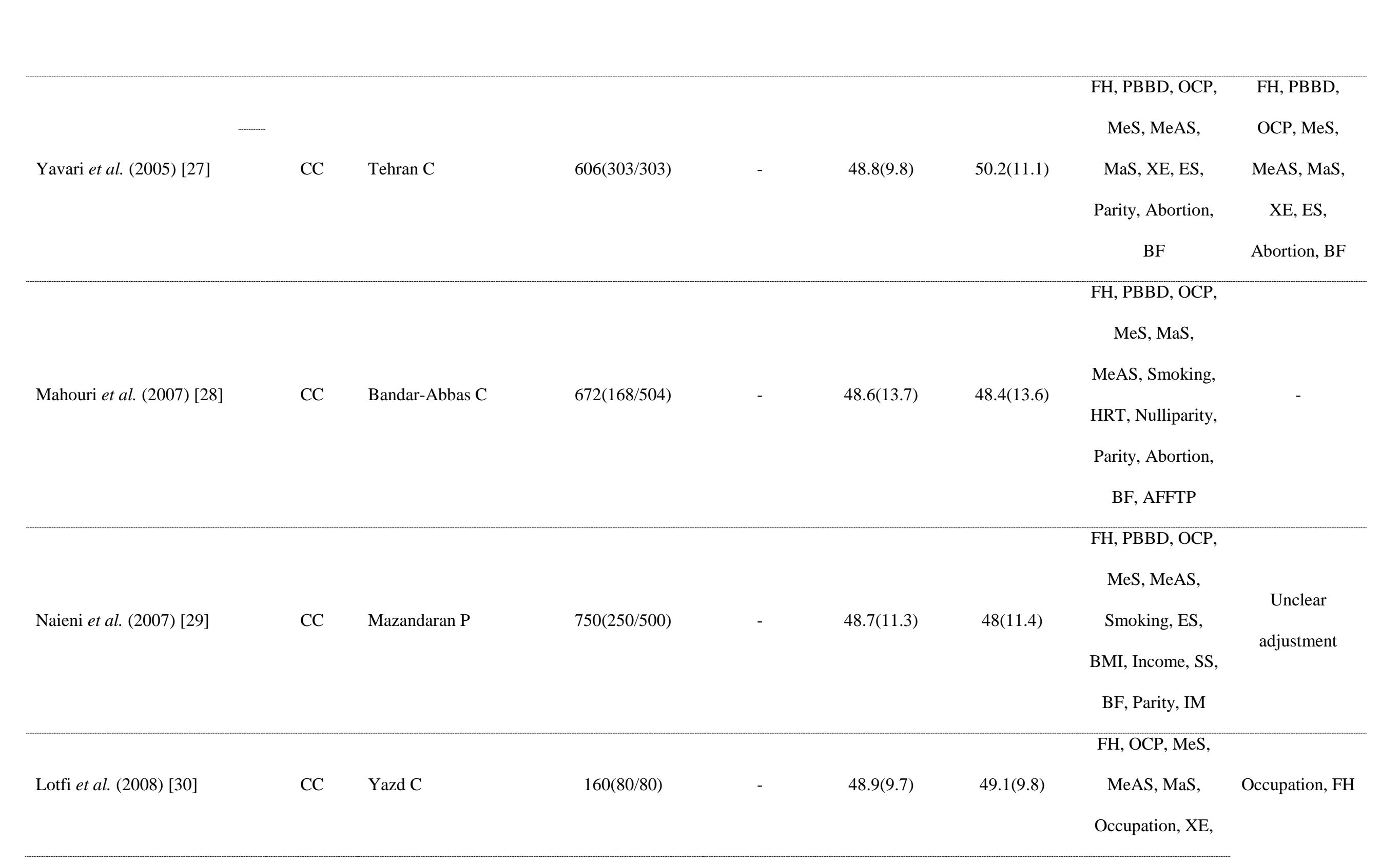




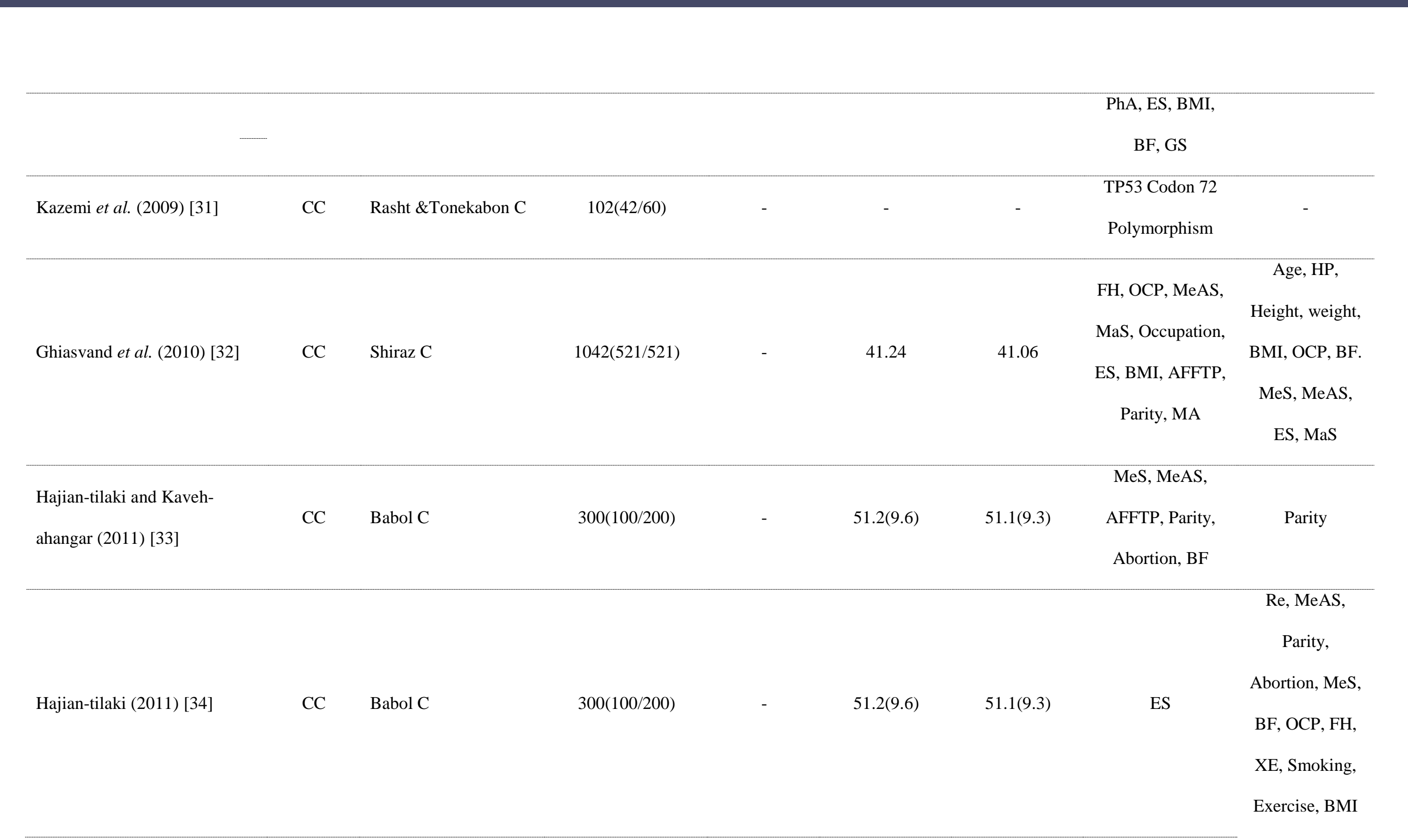




\begin{tabular}{|c|c|c|c|c|c|c|c|c|}
\hline Motie et al. (2011) [35] & $\mathrm{CC}$ & Golestan P & $267(134 / 133)$ & - & $47.15(10.36)$ & $42.96(11.93)$ & $\begin{array}{c}\text { FH, XE, MaS, } \\
\text { MeAS, PBBD, } \\
\text { infertility }\end{array}$ & $\begin{array}{c}\text { Unclear } \\
\text { adjustment }\end{array}$ \\
\hline Ghiasvand et al. (2012) [36] & $\mathrm{CC}$ & Shiraz C & $986(493 / 493)$ & - & $58.2(7.2)$ & $58(7.4)$ & $\begin{array}{c}\text { FH, OCP, MeAS, } \\
\text { Occupation, ES, } \\
\text { BMI }\end{array}$ & Age, Re \\
\hline Sigaroodi et al. (2012) [37] & $\mathrm{CC}$ & Sari C & $130(79 / 51)$ & - & $47.77(12.55)$ & $34.2(9.7)$ & $\begin{array}{c}\text { Age, Human } \\
\text { Papillomavirus }\end{array}$ & - \\
\hline $\begin{array}{l}\text { Ahmadinejad et al. (2013) } \\
\text { [38] }\end{array}$ & $\mathrm{CS}$ & Tehran C & $728(184 / 544)$ & $48.1(8.6)$ & - & $48.6(8.3)$ & $\begin{array}{c}\text { Age, MeS, MaS, } \\
\text { Smoking, Parity, } \\
\text { AFFTP, BMI, } \\
\text { Occupation, Diet }\end{array}$ & $\begin{array}{c}\text { MeAS, Parity, } \\
\text { AFD }\end{array}$ \\
\hline Kaviani et al. (2013) [39] & $\mathrm{CS}$ & Tehran C & 646 & $49.62(11.48)$ & - & - & ER, PR & $\begin{array}{c}\text { Unclear } \\
\text { adjustment }\end{array}$ \\
\hline Pourzand et al. (2013) [40] & $\mathrm{CC}$ & Tabriz C & $400(200 / 200)$ & & $50.05(11.47)$ & $49.91(11.83)$ & GS, SS & - \\
\hline Zare et al. (2013) [41] & $\mathrm{CC}$ & Tabriz \& Tehran & $25592(111 / 25481)$ & - & $49.18(8.86)$ & $46.65(9.4)$ & $\begin{array}{c}\text { Age, FH, } \\
\text { Occupation, OCP, } \\
\text { MeS, MaS, HRT, } \\
\text { ES, BMI, MA }\end{array}$ & $\begin{array}{c}\text { Age, } \\
\text { Occupation, ES, } \\
\text { BMI, MeS, } \\
\text { HRT, OCP }\end{array}$ \\
\hline
\end{tabular}




\begin{tabular}{|c|c|c|c|c|c|c|c|c|}
\hline $\begin{array}{l}\text { Bidgoli and Azarshab (2014) } \\
\text { [42] }\end{array}$ & $\mathrm{CC}$ & Sabzevar C & $176(60 / 116)$ & - & $36.45(7.02)$ & $34.2(5.7)$ & SLE, SI, Diet & - \\
\hline $\begin{array}{l}\text { Hosseinzadeh } \text { et al. (2014) } \\
\text { [43] }\end{array}$ & $\mathrm{CC}$ & Tabriz C & $420(140 / 280)$ & - & $47.6(10.7)$ & $46.8(10.4)$ & $\begin{array}{c}\text { FH, PBBD, OCP, } \\
\text { MeAS, MeS, } \\
\text { MaS, Smoking, } \\
\text { PS, HRT, ES, } \\
\text { BMI, Stress, } \\
\text { Migration, Diet, } \\
\text { Nulliparity, } \\
\text { Abortion, BF, } \\
\text { Infertility }\end{array}$ & $\begin{array}{c}\text { MeS, BF, } \\
\text { PBBD, MeAS, } \\
\text { Parity, AFD, } \\
\text { Abortion, OCP }\end{array}$ \\
\hline Mobarakeh et al. (2014) [44] & $\mathrm{CC}$ & Tehran C & $93(53 / 40)$ & - & $40.02(10.01)$ & $39.78(11.21)$ & BMI, Diet & Age, BMI, ES \\
\hline Sepandi (2014) [45] & $\mathrm{CC}$ & Shiraz C & 11850(197/11653) & - & $49.4(8.7)$ & $40.9(10.5)$ & $\begin{array}{c}\text { FH, OCP, MeS, } \\
\text { MeAS, MaS, } \\
\text { Occupation, ES, } \\
\text { BMI, Nulliparity, } \\
\text { Parity, AFFTP }\end{array}$ & $\begin{array}{c}\text { Age, MeAS, } \\
\text { AFP, } \\
\text { occupation, } \\
\text { Parity, FH, BF, } \\
\text { OCP }\end{array}$ \\
\hline Tazhibi et al. (2014) [46] & $\mathrm{CC}$ & Isfahan P & $257(216 / 41)$ & - & - & - & $\begin{array}{c}\text { OCP, MeS, MaS, } \\
\text { HRT }\end{array}$ & $\begin{array}{l}\text { Occupation, } \\
\text { Age, MaS, }\end{array}$ \\
\hline
\end{tabular}

\begin{tabular}{|c|c|c|c|c|c|c|c|c|}
\hline $\begin{array}{l}\text { Bidgoli and Azarshab (2014) } \\
\text { [42] }\end{array}$ & $\mathrm{CC}$ & Sabzevar C & $176(60 / 116)$ & - & $36.45(7.02)$ & $34.2(5.7)$ & SLE, SI, Diet & - \\
\hline $\begin{array}{l}\text { Hosseinzadeh } \text { et al. (2014) } \\
\text { [43] }\end{array}$ & $\mathrm{CC}$ & Tabriz C & $420(140 / 280)$ & - & $47.6(10.7)$ & $46.8(10.4)$ & $\begin{array}{c}\text { FH, PBBD, OCP, } \\
\text { MeAS, MeS, } \\
\text { MaS, Smoking, } \\
\text { PS, HRT, ES, } \\
\text { BMI, Stress, } \\
\text { Migration, Diet, } \\
\text { Nulliparity, } \\
\text { Abortion, BF, } \\
\text { Infertility }\end{array}$ & $\begin{array}{c}\text { MeS, BF, } \\
\text { PBBD, MeAS, } \\
\text { Parity, AFD, } \\
\text { Abortion, OCP }\end{array}$ \\
\hline Mobarakeh et al. (2014) [44] & $\mathrm{CC}$ & Tehran C & $93(53 / 40)$ & - & $40.02(10.01)$ & $39.78(11.21)$ & BMI, Diet & Age, BMI, ES \\
\hline Sepandi (2014) [45] & $\mathrm{CC}$ & Shiraz C & 11850(197/11653) & - & $49.4(8.7)$ & $40.9(10.5)$ & $\begin{array}{c}\text { FH, OCP, MeS, } \\
\text { MeAS, MaS, } \\
\text { Occupation, ES, } \\
\text { BMI, Nulliparity, } \\
\text { Parity, AFFTP }\end{array}$ & $\begin{array}{c}\text { Age, MeAS, } \\
\text { AFP, } \\
\text { occupation, } \\
\text { Parity, FH, BF, } \\
\text { OCP }\end{array}$ \\
\hline Tazhibi et al. (2014) [46] & $\mathrm{CC}$ & Isfahan P & $257(216 / 41)$ & - & - & - & $\begin{array}{c}\text { OCP, MeS, MaS, } \\
\text { HRT }\end{array}$ & $\begin{array}{l}\text { Occupation, } \\
\text { Age, MaS, }\end{array}$ \\
\hline
\end{tabular}


HRT, Abortion,

BMI

FH, OCP, MeS,

MaS, Smoking,

PS, Occupation,

XE, PhA, ES,

Dianatinasab et al. (2017) [55] CC Shiraz C

Hair coloring,

BMI, Stress, SQ,

MaS, AFD,

Parity, Birth

Spacing, BF,

MeAS

Parity, AFFTP,

$\mathrm{BF}$

Age, FH,

Dianatinasab-2 et al. (2017)

[56]

CS Shiraz C

497

47.7(10.57)

Smoking, XE,

$\mathrm{PhA}$, Income, CD

FH, MaS, ES, RR

Mirfarhadi et al. (2017) [57]

CS Rasht C

232

42.82(10.23)

IC, Income

Age, BMI, ES,

$\begin{array}{llllll}\text { Vahid } \text { et al. (2017) [58] } \quad \text { CC } \quad \text { Tehran C } & \text { 293(145/148) } & - & 49.8(11.8) & \text { 48.5(11.9) }\end{array}$

MeAS, 


\begin{tabular}{|c|c|c|c|c|c|c|c|c|}
\hline Fararouei et al. (2018) [59] & $\mathrm{CC}$ & Shiraz C & $1010(505 / 505)$ & - & $41.78(10.56)$ & $42.24(10.62)$ & $\begin{array}{c}\text { FH, OCP, } \\
\text { Smoking, PS, } \\
\text { Occupation, PhA, } \\
\text { ES, MA, Diet }\end{array}$ & $\begin{array}{c}\text { Diet, PhA, ES, } \\
\text { Occupation, } \\
\text { PBBD, OCP, } \\
\text { Smoking }\end{array}$ \\
\hline Pouladi et al. (2018) [60] & $\mathrm{CC}$ & Tabriz C & $303(143 / 160)$ & - & - & - & $\begin{array}{l}\text { TP53 Codon } 72 \\
\text { Polymorphism }\end{array}$ & - \\
\hline Vahid et al. (2018) [61] & $\mathrm{CC}$ & Tehran C & $293(145 / 148)$ & - & $49.83(11.86)$ & $48.54(12)$ & ER, PR & $\begin{array}{c}\text { Age, ES, } \\
\text { Exercise, BMI, } \\
\text { Smoking, FH, } \\
\text { MeAS, Parity, } \\
\text { MaS, MeS, } \\
\text { OCP, HRT }\end{array}$ \\
\hline Marzbani et al. (2019) [62] & $\mathrm{CC}$ & Kermanshah C & $620(212 / 408)$ & - & $41.5(6.2)$ & $39.5(7.1)$ & $\begin{array}{l}\text { Age, MaS, ES, } \\
\text { BMI, Diet, RR, } \\
\text { IC, Occupation }\end{array}$ & $\begin{array}{c}\text { Age, Sex, ES, } \\
\text { BMI }\end{array}$ \\
\hline
\end{tabular}

\footnotetext{
C: City, P: Province, CC: Case-control, CS: Cross-sectional, FH: Familial history, OCP: Oral contraceptive pill, MeS: Menopause status, MaS: Marital status ES: Educational status, AFFTP: Age at first full-term pregnancy, HRT: Hormone replacement therapy, SLE: Sunlight exposure, SI: Supplement intake, XE: X-ray Exposure, PhA: physical activity CD: Chronic diseases, PS: Passive smoker, SQ: Sleep Quality, MeAS: Menarche age status, BF: Breastfeeding, IM: Irregular menstruation, PBBD: Previous benign breast disease, RR: Rural residency,
} 


\section{Quality assessment}

According to quality assessment using NOS checklist, 39 studies earned the minimum eligibility score and entered into the meta-analysis. It is remarkable that NOS modified checklist used for cross-sectional studies [63]. Only one paper excluded due to a low score. Summary of risk of bias presented in Fig. 2. for details see Additional file.
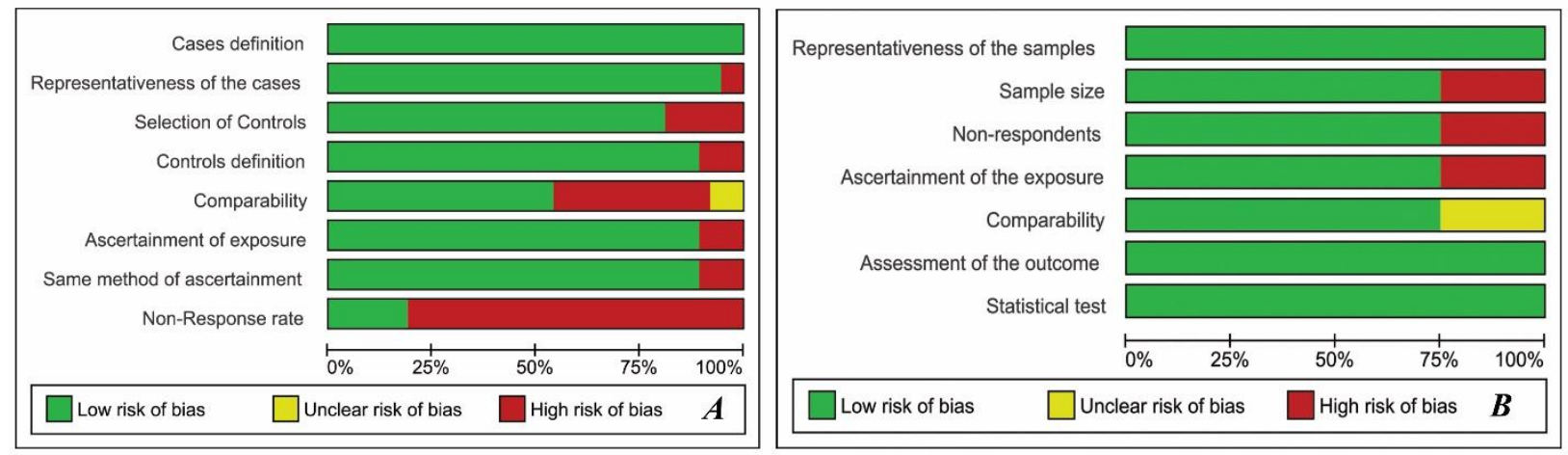

Fig. 2 Risk of bias summary. A: Case-control studies; B: Cross-sectional studies

\section{Risk factors for breast cancer}

According to included studies, over 20 risk factors were reported for breast cancer. The factors reported in only one study, which seems to be rare are as follows: High fat foods and dairy (e.g. milk, yogurt and cheese), Fast foods, Genital surgery, Hopelessness, Hair coloring, Human papillomavirus infection, Epstein-Barr virus infection, Ovarian cancer, Supplements of selenium, calcium, Vit B12 and Vit D.

The factors reported in more than one study are as follows: Age, Family history, Menarche age, Body mass index (BMI), Relationship status, Education Level, Stress conditions, Smoking status, Daily exercise, Hormone receptor status, Menopausal status, Hormone replacement therapy (HRT), Oral contraceptive, Birth giving status, Abortion status, Benign Breast Conditions, X-ray 
exposure, Breastfeeding duration, Dietary status (including sweets, egg, fish, and vegetables), Genotype status and Residency status.

Only clear well-known risk factors reported in two or more studies entered into the meta-analysis.

\section{Individual-related risk factors (Table 2)}

Age

Age was considered as a risk factor in four papers. The meta-analysis showed no significant difference between groups for breast cancer occurrence regarding age (OR: 1.04, 95\%CI 0.971.11). A significant heterogeneity was observed $\left(I^{2}=80.6 \%, P=0.023\right)$ (Additional file).

\section{Family history}

Eighteen studies reported on family history of breast cancer. The meta-analysis between two groups showed that the odds of breast cancer development was 1.80 times higher in subject with a family history of breast cancer (OR: 1.80, 95\%CI 1.47-2.12). A modest heterogeneity was observed $\left(I^{2}=24.3 \%, P=0.205\right)$ (Fig. 3). 


\begin{tabular}{|c|c|c|}
\hline \multicolumn{3}{|l|}{ Study } \\
\hline \multicolumn{2}{|l|}{ ID } & $\mathrm{ES}(95 \% \mathrm{CI})$ \\
\hline Montazeri (2004) & $\leftarrow$ & $2.48(1.48,4.14)$ \\
\hline Naieni (2007) & $\rightarrow$ & $3.14(1.37,7.20)$ \\
\hline Lotfi (2008) & $\rightarrow$ & $5.71(1.22,26.58)$ \\
\hline Ghiasvand (2010) & - & $1.61(1.07,2.42)$ \\
\hline Motie (2011) & $\hookleftarrow$ & $1.07(0.22,5.24)$ \\
\hline Ghiasvand (2012) & $\leftarrow$ & $2.61(1.72,3.96)$ \\
\hline Zare (2013) & + & $2.64(1.24,5.60)$ \\
\hline Sepandi (2014) & $\bullet$ & $1.54(0.96,2.46)$ \\
\hline Jafarinia (2016) & - & $6.78(2.15,21.41)$ \\
\hline Dehghan (2017) & $\rightarrow$ & $3.24(1.17,4.51)$ \\
\hline Dianatinasab (2017) & $\bullet$ & $1.34(0.87,2.03)$ \\
\hline Fararouei (2018) & $\infty$ & $3.41(1.93,6.01)$ \\
\hline Overall (I-squared $=24.3 \%, p=0.205$ ) & 1 & $1.80(1.47,2.12)$ \\
\hline $\begin{array}{c}1 \\
-26.6\end{array}$ & 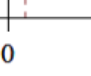 & \\
\hline
\end{tabular}

Fig 3 Forest plot for pooling adjusted odds ratio of family history

\section{Menarche age}

This factor was studied in Nine articles. The meta-analysis showed a significant protective effect for menarche age more than 15 (OR: 0.58 , 95\%CI $0.32-0.83$ ). Moderate heterogeneity was observed in this regard $\left(I^{2}=35.3 \%, P=0.201\right)$ (Fig. 4$)$. 
Study

ID

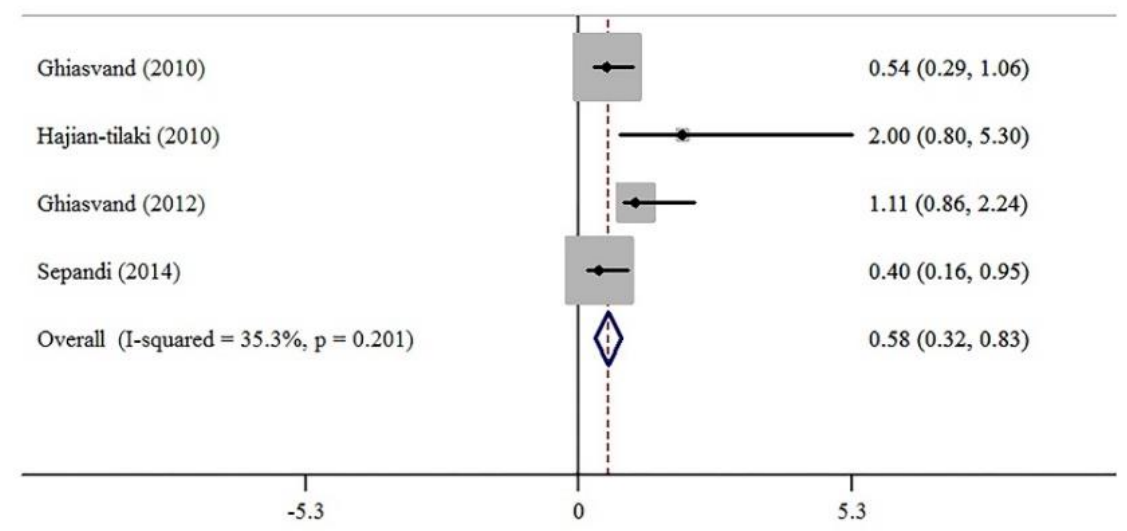

Fig. 4 Forest plot for pooling adjusted odds ratio of menarche age more than 15 years

\section{Body mass index}

BMI investigated in nine studies. The meta-analysis indicated no significant differences between groups for BMI status (OR: 1.04, 95\%CI 0.99-1.09), BMI 25-29.9 (OR: 1.07, 95\%CI 0.82-1.32) and BMI more than 30 (OR: 1.21, 95\%CI 0.90-1.52) (Additional file).

\section{Relationship status}

Thirteen papers were studied relationship status. The meta-analysis, found that there were no significant differences between groups regarding single status (crude OR: 0.98, 95\%CI 0.74-1.23), married status (crude OR: 0.64, 95\%CI -0.25-1.54) and divorced status (crude OR: 1.15, 95\%CI 0.87-1.43) (Additional file).

\section{Education Level}


This factor was studied in 15 papers. According to meta-analysis, no significant differences were found for both basic education level (OR: 1.18, 95\%CI 0.70-1.66) and academic education level (OR: 0.67, 95\%CI 0.24-1.10) (Additional file).

\section{Stress conditions}

This factor was studied in three papers. The meta-analysis found a significantly higher chance of breast cancer occurrence in cases who experienced stressful conditions (OR: 2.67, 95\%CI 1.843.50). No heterogeneity was observed $\left(I^{2}=0.0 \%, P=0.384\right)$ (Fig. 5).

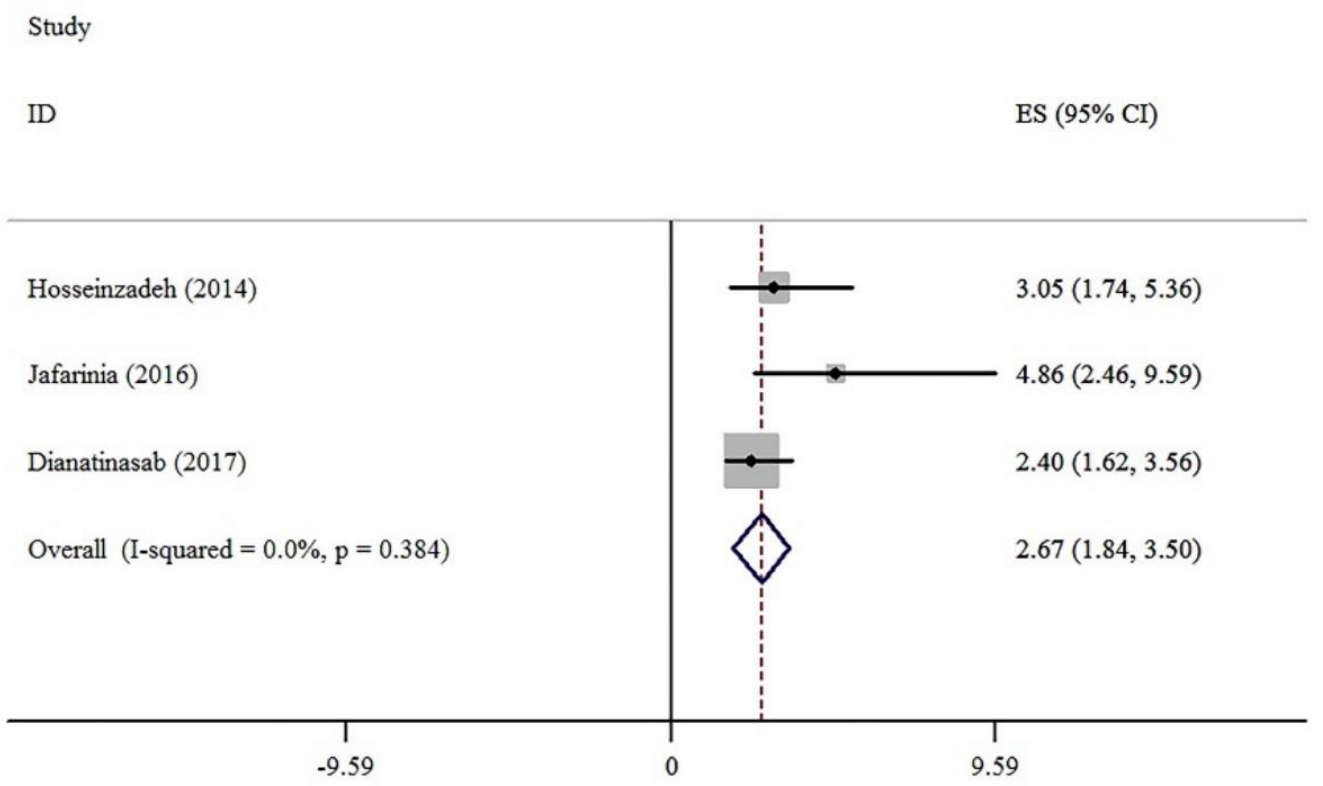

Fig. 5 Forest plot for pooling adjusted odds ratio of stress conditions experience

\section{Smoking status}


Six papers studied this factor. The meta-analysis showed that the odds of breast cancer occurrence was 1.68 times higher in the passive smokers (OR: 1.68, 95\%CI 1.34-2.03). However, no significant relationships were observed for active smokers (OR: 1.70, 95\%CI 0.66-2.74) (Additional file).

\section{Daily exercise}

Three studies were included with this factor. The daily exercise showed a protective effect on the occurrence of breast cancer (OR: 0.59, 95\%CI 0.44-0.73). No heterogeneity was observed $\left(I^{2}=0.0 \%, P=0.678\right)$ (Additional file).

\section{Hormone receptor status}

Two studies were investigated ER and PR status. The meta-analysis showed a significant higher chance of breast cancer occurrence in both ER-positive subjects (OR: 1.87, 95\%CI 1.41-2.33) and PR-positive subjects (OR: $1.84,95 \%$ CI $1.38-2.29)$. No heterogeneity was observed $\left(I^{2}=0.0 \%\right.$, $P>0.05)$ (Additional file).

\section{Menopausal status}

Thirteen studies have investigated this factor. No significant relationships were observed between groups in this regard (OR: $1.29,95 \% \mathrm{CI} 0.84-1.74)$. High heterogeneity was observed $\left(I^{2}=73.9 \%\right.$, $P<0.0001)$ (Additional file).

\section{Hormone replacement therapy}

HRT was studied in five paper. The meta-analysis indicated that the odds of breast cancer occurrence was 5.48 time higher in the group with HRT history (OR: 5.48, 95\%CI 0.84-1.74). No significant heterogeneity was observed $\left(I^{2}=0.0 \%, P=0.509\right)$ (Fig. 6). 


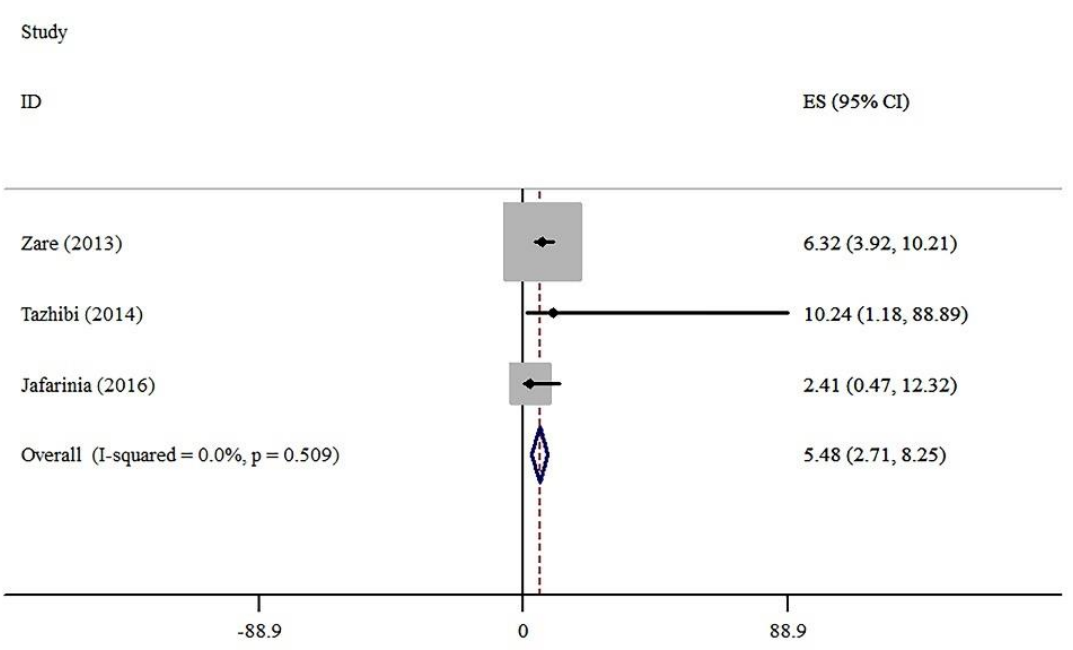

Fig. 6 Forest plot for pooling adjusted odds ratio of hormone replacement therapy

\section{Oral contraceptive}

History of OCP intake was discussed in 15 papers. The meta-analysis showed no significant differences between groups in this regard (OR: 1.17, 95\%CI 0.77-1.57). High heterogeneity was observed $\left(I^{2}=86.9 \%, P<0.0001\right)$ (Additional file).

\section{Birth giving status}

Age at first full-term pregnancy was considered in six studies. Meta-analysis showed a significant difference for age 20 to 24 (OR: 1.92, 95\%CI 1.14-2.71) and age 30 (OR: 3.41, 95\%CI 1.19-5.63) in this regard, but no substantial relationships were found for age 25 to 29 (OR: $1.55,95 \%$ CI 0.82 2.29) (Additional file).

Six studies investigated the relation of nulliparity and chance of breast cancer development. The meta-analysis results indicated that this condition has an inverse relation with the occurrence of breast cancer (OR: 0.68, 95\%CI 0.39-0.96) (Additional file). 
Moreover, five papers studied the history of abortion. A significant difference in odds was observed in the meta-analysis of two groups. Subjects with a history of abortion have a higher chance of breast cancer development (OR: 1.84, 95\%CI 1.35-2.33). No significant heterogeneity was observed $\left(I^{2}=0.0 \%, P=0.393\right)$ (Additional file).

\section{Benign Breast Conditions}

Data from five studies were combined for the meta-analysis of benign breast history as a risk factor to develop breast cancer. No significant difference was observed in this regard (crude OR: 1.24, 95\%CI 0.82-1.67) (Additional file).

\section{$X$-ray exposure}

This factor was studied in four papers. No significant differences were observed regarding the history of X-rays exposure between cases and controls (OR: 1.02, 95\%CI 0.19-1.86). A significant heterogeneity was observed $\left(I^{2}=83.6 \%, P=0.002\right)$ (Additional file).

\section{Breastfeeding duration}

This factor investigated in seven studies. The meta-analysis revealed that 13 to 24 months of breastfeeding has an inverse association with breast cancer occurrence (OR: $0.68,95 \%$ CI $0.46-$ 0.90). No significant heterogeneity was observed $\left(I^{2}=0.0 \%, P=0.624\right)$ (Additional file).

\section{Dietary status}

This factor was studied for egg, fish, sweets and vegetables. The meta-analysis revealed that egg (crude OR: 0.92, 95\%CI -0.64-2.47) and fish (crude OR: 1.47, 95\%CI 0.68-2.25) do not affect the chance of breast cancer occurrence significantly (Additional file). However, findings showed that the odds of developing breast cancer were higher in individuals with high sweets consumption 
(OR: 1.71, 95\%CI 1.32-2.11) (Additional file) and lower in subjects with regular vegetable consumption (crude OR: 0.28, 95\%CI 0.10-0.46) (Fig. 7).

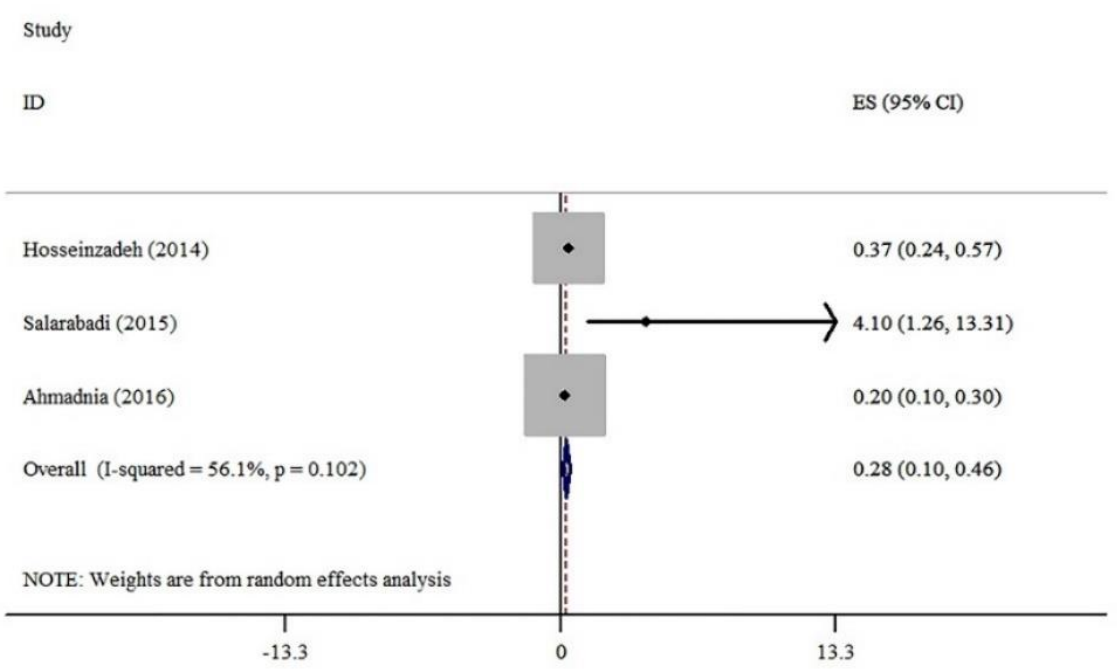

Fig. 7 Forest plot for pooling odds ratio of vegetable consumption

\section{Genotype status}

Two studies were investigated p53 codon 72 polymorphisms as a breast cancer risk factor. Although genotype Arg/Pro (crude OR: 0.69, 95\%CI 0.37-1.00) was not related to the odds of breast cancer development, a significant higher chance found for genotype Arg/Arg (crude OR: $1.59,95 \%$ CI 1.07-2.10) in this regard (Additional file).

\section{Genital surgery}

Genital surgery was considered in two studies. No significant differences were found regarding the history of genital surgery for breast cancer development (crude OR: 1.37, 95\%CI 0.87-1.86) (Additional file).

\section{Residency status}


Place of living was investigated in two studies. The meta-analysis delivered no significant difference between two groups with rural and urban residency status for breast cancer occurrence (crude OR: 1.37, 95\%CI 0.87-1.86) (Additional file). 
Table 2 Summarized Pooled ORs of Considered Risk Factors

\begin{tabular}{|c|c|c|c|c|c|c|c|c|}
\hline Risk Factor & $\begin{array}{l}\text { Number } \\
\text { of studies }\end{array}$ & $\begin{array}{l}\text { I-squared; } \\
\text { Crude, \% }\end{array}$ & $\begin{array}{l}P \text {-value; } \\
\text { Crude }\end{array}$ & $\begin{array}{c}\text { OR }(95 \% \text { CI }) \\
\text { Crude }\end{array}$ & $\begin{array}{l}\text { Number } \\
\text { of studies }\end{array}$ & $\begin{array}{c}\text { I-squared; } \\
\text { Adjusted, \% }\end{array}$ & $\begin{array}{l}P \text {-value; } \\
\text { Adjusted }\end{array}$ & $\begin{array}{c}\text { OR (95\% CI); } \\
\text { Adjusted }\end{array}$ \\
\hline Age & 5 & 94.2 & 0.000 & $0.97(0.92,1.02)$ & 2 & 80.6 & 0.023 & $1.04(0.97,1.11)$ \\
\hline Family history & 18 & 24.6 & 0.165 & $2.31(1.95,2.86)$ & 12 & 24.3 & 0.205 & $1.80(1.47,2.12)$ \\
\hline \multicolumn{9}{|l|}{ Menarche age status } \\
\hline Unknown categorization & 2 & 89.6 & 0.002 & $2.25(-0.80,5.30)$ & - & - & - & - \\
\hline Less than 12 years & 5 & 81.4 & 0.000 & $1.31(0.23,2.40)$ & - & - & - & - \\
\hline Between 12 to 15 years & 2 & 54.8 & 0.137 & $0.52(0.26,0.78)$ & 2 & 77.3 & 0.036 & $0.55(0.07,1.03)$ \\
\hline Less than 13 years & 5 & 0.0 & 0.710 & $1.19(0.94,1.44)$ & - & - & - & - \\
\hline Less than 14 years & 5 & 38.6 & 0.164 & $0.91(0.68,1.15)$ & - & - & - & - \\
\hline More than 15 years & 5 & 75.5 & 0.003 & $0.81(0.39,1.23)$ & 4 & 35.3 & 0.201 & $0.58(0.32,0.83)$ \\
\hline \multicolumn{9}{|l|}{ Body mass index status } \\
\hline Unknown categorization & 3 & 65.3 & 0.056 & $1.02(1.00,1.05)$ & 2 & 77.9 & 0.034 & $1.04(0.99,1.09)$ \\
\hline Between 25-29.9 & 6 & 0.0 & 0.699 & $1.09(0.91,1.28)$ & 3 & 0.0 & 0.766 & $1.07(0.82,1.32)$ \\
\hline More than 30 & 5 & 0.0 & 0.433 & $1.15(0.91,1.39)$ & 3 & 0.0 & 0.994 & $1.21(0.90,1.52)$ \\
\hline
\end{tabular}

Relationship status

$\begin{array}{lcccc}\text { Single } & 11 & 13.6 & 0.315 & 0.98(0.74,1.23) \\ \text { Married } & 2 & 0.0 & 0.678 & 0.64(-0.25,1.54) \\ \text { Divorced } & 7 & 0.0 & 0.619 & 1.15(0.87,1.43)\end{array}$

Education Level

Basic Education
Academic Education

Stress conditions

Smoking status

$$
\begin{aligned}
& \text { Active Smoker } \\
& \text { Passive Smoker }
\end{aligned}
$$

Daily exercise

Hormone receptor status

Estrogen Receptor +

Progesterone Receptor +

Menopausal status

Hormone replacement therapy

Oral contraceptive

Age at first full-term pregnancy
14

12

3

2

4

75.5

71.4

52.2

63.5

0.0

73.5

0.657

0.010
87.5

69.8

0.0

66.3

0.0

0.0

0.0

0.0

73.9

0.0

86.9

0.000

0.002

0.384

0.051

0.442

0.678

$0.59(0.44,0.73)$

12

4

14
88.9

61.9

80.0
0.000

0.049

0.000
$1.80(0.36,3.23)$

$1.18(0.93,1.44)$
3

10
0.956

0.770

0.000

0.509

0.000
$1.87(1.41,2.33)$

$1.84(1.38,2.29)$

$1.29(0.84,1.74)$

$5.48(2.71,8.25)$

$1.17(0.77,1.57)$ 


\begin{tabular}{|c|c|c|c|c|c|c|c|c|}
\hline 20 to 24 years & 3 & 68.0 & 0.044 & $1.48(0.79,2.17)$ & 2 & 0.0 & 0.484 & $1.92(1.14,2.71)$ \\
\hline 25 to 29 years & 5 & 0.0 & 0.560 & $1.40(1.00,1.80)$ & 4 & 5.3 & 0.367 & $1.55(0.82,2.29)$ \\
\hline 30 years & 5 & 0.0 & 0.758 & $2.23(1.45,3.01)$ & 3 & 0.0 & 0.970 & $3.41(1.19,5.63)$ \\
\hline
\end{tabular}

\section{Birth giving status}

Nulliparity

Abortion

Previous benign breast

$\mathrm{X}$-ray exposure

Breastfeeding duration

Breastfeeding

1 to 12 months

13 to 24 months

25 to 48 months

More than 49 months

Dietary status

Egg
Fish
Sweets
Vegetables

\section{Genotype status}

Genital surgery

Residency status

Rural

\begin{tabular}{ccccccc} 
Arg/Arg & 2 & 0.0 & 0.835 & $1.59(1.07,2.10)$ & - & - \\
Arg/Pro & 2 & 0.0 & 0.824 & $0.69(0.37,1.00)$ & - & - \\
Genital surgery & 2 & 0.0 & 0.325 & $2.23(0.91,3.55)$ & - & - \\
Residency status & & & & & - \\
Rural & 2 & 0.0 & 0.875 & $1.37(0.87,1.86)$ & - & - \\
\hline
\end{tabular}

6

5

5

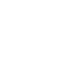

40.4
86.9
0.0
0.0

$\begin{array}{ll}0.136 & 0.77(0.55,0.98) \\ 0.000 & 1.25(0.57,1.93) \\ 0.672 & 1.24(0.82,1.67) \\ 0.676 & 1.42(1.18,1.66)\end{array}$

3
3

$\begin{array}{cccc}3 & 0.0 & 0.526 & 0.58(0.30,0.85) \\ 3 & 40.0 & 0.189 & 0.95(0.41,1.49) \\ 4 & 0.0 & 0.602 & 0.57(0.42,0.72) \\ 2 & 92.1 & 0.000 & 1.12(-0.68,2.92) \\ - & - & - & -\end{array}$

$\begin{array}{cccc}2 & 88.1 & 0.004 & 0.73(0.14,1.31) \\ - & - & - & - \\ 2 & 0.0 & 0.624 & 0.68(0.46,0.90) \\ 2 & 0.0 & 0.402 & 0.24(-0.46,0.94) \\ 2 & 0.0 & 0.410 & 0.10(-0.25,0.44)\end{array}$




\section{Discussion:}

We undertook this systematic review and meta-analysis to identify the risk factors that contribute to the occurrence of female breast cancer in Iran. Out of 39 included papers, more than 60 factors were studied as breast cancer risk factors, of which only 27 factors entered into the meta-analysis. Out of these 27 risk factors, 11 factors including family history, HRT, ER and PR positive status, stress condition, passive smokers, late full-term pregnancy, abortion, sweets consumption and genotype Arg/Arg indicated to be significantly associated with a higher chance of breast cancer development. In contrast, five factors of late menarche, nulliparity, 13 to 24 months of breastfeeding, daily exercise and vegetable consumption, demonstrated to be protective factors in this regard. The other remaining risk factors were not associated with the development of breast cancer.

Family history of breast cancer was one of the associated risk factors for breast cancer development in our study. In one of the first meta-analysis on "Family history and the risk of breast cancer", Pharoah et al. [64] pooled estimate of relative risk (RR) indicated that the probability of breast cancer occurrence is higher in those individuals with a family history of this malignancy (RR: 1.9, 95\%CI, 1.7-2.0). They also found that this probability is higher in the first-degree relatives, especially mother and sister (RR: 3.6, 95\%CI 2.5-5.0). There are many other studies that reported the association of family history with the risk of breast cancer [65-67].

High levels of estrogen can increase the chance of breast cancer development through genotoxic stress induction and breast tissue mutations $[68,69]$. Therefore, receiving external estrogen through HRT may increase the risk of breast cancer development. In this regard, HRT users showed the highest chance of developing breast cancer in our meta-analysis (OR: 5.48, 95\%CI 0.84-1.74), in 
consistent with several studies [70-72]. In contrast, study of Bae et al. reported no significant association in this regard among Korean Women [73].

The first systematic review on "Adverse life-events and risk of breast cancer" [74] indicated no significant relationships in this regard (OR: 0.8, 95\%CI 0.96-1.06) and two other systematic reviews reported the same conclusion $[75,76]$. Our results were contrary to these studies, but was in the same line with the study of Lin et al. that demonstrated significant evidence for a positive relationship between life stressful events and risk of breast cancer (OR: 1.51, 95\%CI 1.15-1.97, $P=0.003)$ [77].

In our meta-analysis, although passive smokers were at higher risk of breast cancer development, no significant association was found for active smokers in this case. Our findings were in the same line with the systematic review of Chen et al. [78] among Chinese females, which implied that passive smokers were at higher risk of breast cancer development (OR: 1.62, 95\%CI 1.39-1.85), but not active smokers (OR: 1.04, 95\%CI 0.89-1.20). Moreover, some other studies reported a significant association between passive smoking and the risk of breast cancer [79-81].

In regard to the age at first full-term pregnancy, our results were in the same line with previous studies regarding the higher risk of breast cancer at age 30 or older ages [82,83]. For nulliparity condition, our study showed an inverse association with breast cancer development, which was in contrast with several previous reports $[84,85]$.

Numerous investigators have studied the association of induced abortion and risk of breast cancer throughout the world. One of the oldest studies titled "Induced abortion as a cancer risk factor" discussed the induced abortion as a breast cancer risk factor [86]. Similarly, some meta-analysis also reported the same conclusions $[87,88]$. In this regard, our meta-analysis found that induced abortion was significantly associated with risk of breast cancer in Iranian women. Besides, the 
study of Deng et al. demonstrated that induced abortion might be associated with risk of breast cancer in parous women (OR: $1.11,95 \% \mathrm{CI}, 1.02-1.20, P=0.01)$, but not in nulliparous women (OR:1.02, 95\%CI, 0.86-1.21, $P=.85)$. In contrast, several studies arrived at contradictory conclusions $[89,90]$.

The meta-analysis findings showed the significant association between sweet foods consumption and risk of breast cancer. Although we did not find a specific systematic review in this regard, several epidemiological studies in different regions reported the association of sweet foods consumption and risk of breast cancer [91-94]. For example, Tavani et al. performed a comprehensive case-control study in Italy and found a direct relationship between sweet foods consumption and risk of breast cancer development [94]. In fact, excessive sweets intake with a high glycemic index may cause insulin resistance as well as insulin-related growth factors as promoters of breast carcinogenesis. Moreover, ovarian steroid secretion including estrogens and androgens might be stimulated by insulin. Altogether, these processes end up in increased risk of breast cancer $[95,96]$.

Previous studies have investigated the relationships of P53 codon 72 polymorphisms and risk of breast cancer development in different regions [97]. In this investigation, we found that the genotype Arg/Arg is associated with the development of breast cancer, which was in consistent with the study of Al-Qasem et al. among Saudi women, and in contrast with meta-analysis carried out by Ma et al. and Hou et al. studies [98,99].

Menarche age does not exactly match with the breast cancer onset. However, they are significantly correlated [100]. This meta-analysis demonstrated an inverse association between late menarche age and risk of breast cancer (OR: $0.58,95 \%$ CI 0.32-0.83). Our findings were along the same 
direction with two other meta-analyses carried out by Li et al. [101] and Collaborative Group on Hormonal Factors in Breast Cancer [102].

We found that longer breastfeeding duration (13 to 24 months) plays a protective rule against breast cancer development, in consistent with numerous meta-analysis in various populations [103-106]. In this regard, according to one of the most comprehensive studies on "Breast cancer and breastfeeding" including 47 epidemiological studies in 30 countries, breast cancer development would be reduced by $42 \%$, especially in developing countries because women in these countries usually have a long duration of breastfeeding throughout their lives [107]. In contrast, short breastfeeding duration, which is usual among women in developed countries with small family size, would contribute to a higher risk of breast cancer development in such countries [107].

The updated report "Food, Nutrition, Physical Activity, and the Prevention of Cancer: A Global Perspective" in 2007, recommended physical activity as a protective factor against cancers, especially postmenopausal breast cancer [108]. It was also recommended by "American Cancer Society Guidelines on nutrition and physical activity for cancer prevention" [109]. Our findings also support this hypothesis as a preventive factor for breast cancer development. In fact, physical activities effect on the risk of cancers development through mechanisms such as metabolic, reproductive effects, hormonal, and immunity enhancement, etc. [110]. The comprehensive study of Moore et al. titled "Association of Leisure-Time Physical Activity with Risk of 26 Types of Cancer in 1.44 Million Adults" reported the significant association for high and low physical activity and lower risk of breast cancer (hazard ratio (HR): 0.9, 95\% CI, 0.87-0.93).

The association between vegetables intake and risk of breast cancer was always controversial. Our results suggest a protective effect of vegetable consumption on risk of breast cancer. In the same 
direction, meta-analyses carried out by Liu et al., Woo et al. and Aune et al. indicated a significant association between various types of vegetables and dietary fiber consumption and risk of breast cancer development [111-113]. In contrast, several systematic reviews and meta-analysis showed no significant relationships in this regard [114,115] and some others were controversial regarding the types of vegetables and its combination intake with fruits as well as breast cancer types $[116,117]$.

According to the retrospective nature of the included studies, it is recommended to design some longitudinal cohort investigations in order to examine the accurate role of these risk factors in breast cancer development.

\section{Conclusion:}

Based on this systematic review and meta-analysis, factors including a family history of breast cancer, HRT, ER and PR positive status, the experience of stress condition, passive smokers, abortion, sweets consumption and genotype Arg/Arg, play a significant role in the development of breast cancer. In contrast, late menarche, nulliparity, long breastfeeding duration, regular physical activity and consumption of vegetables showed a significant inverse association with breast cancer occurrence.

\section{Ethics approval}

It is only remarkable that the protocol of this systematic review and meta-analysis registered in International Prospective Register of Systematic Reviews (PROSPERO) due to code CRD42019127382.

\section{Conflict of interests}

The authors declare that they have no conflict of interests. 


\section{Funding}

None. 


\section{References:}

1. Clegg LX, Reichman ME, Miller BA, Hankey BF, Singh GK, Lin YD, Goodman MT, Lynch CF, Schwartz SM, Chen VW (2009) Impact of socioeconomic status on cancer incidence and stage at diagnosis: selected findings from the surveillance, epidemiology, and end results: National Longitudinal Mortality Study. Cancer causes \& control 20 (4):417-435

2. Ferlay J, Soerjomataram I, Dikshit R, Eser S, Mathers C, Rebelo M, Parkin DM, Forman D, Bray F (2015) Cancer incidence and mortality worldwide: sources, methods and major patterns in GLOBOCAN 2012. International journal of cancer 136 (5):E359-E386

3. Mahboubi A, Alvandi S, ALIZADEH NR (2004) An analytical survey on breast lesions in mammography.

4. Mousavi SM, Gouya MM, Ramazani R, Davanlou M, Hajsadeghi N, Seddighi Z(2008) Cancer incidence and mortality in Iran. Annals of oncology 20 (3):556-563

5. Dean T, Armando E (2002) Breast cancer. novak, Berek J, editors. Novak's gynecoloy. 13th. Philadelphia: Lippincott William \& Wilkins,

6. Harris J, Lippman M, Morrow M, Osborne C (2014) Diseases of the breast 5th ed. Philadelphia: Wolters Kluwer/Lippincott Williams \& Wilkins Health,

7. Fitzmaurice C, Dicker D, Pain A, Hamavid H, Moradi-Lakeh M, MacIntyre MF, Allen C, Hansen G, Woodbrook R, Wolfe C (2015) The global burden of cancer 2013. JAMA oncology 1 (4):505-527

8. Jemal A, Bray F, Center MM, Ferlay J, Ward E, Forman D (2011) Global cancer statistics. CA: a cancer journal for clinicians 61 (2):69-90

9. Parkin D, Läärä E, Muir C (1988) Estimates of the worldwide frequency of sixteen major cancers in 1980. International journal of cancer 41 (2):184-197

10. Izquierdo A, Gispert R, Saladie F, Espinàs JA (2008) Análisis de la incidencia, la supervivencia y la mortalidad según las principales localizaciones tumorales, 1985-2019: cáncer de mama. Medicina clínica 131:50-52 
11. Hortobagyi GN, de la Garza Salazar J, Pritchard K, Amadori D, Haidinger R, Hudis CA, Khaled H, Liu M-C, Martin M, Namer M (2005) The global breast cancer burden: variations in epidemiology and survival. Clinical breast cancer $6(5): 391-401$

12. YektaKooshali M, Esmaeilpour-Bandboni M, Sharemi S, Alipour Z (2016) Survival rate and average age of the patients with breast cancer in Iran: systematic review and meta-analysis. Journal of Babol University Of Medical Sciences 18 (8):29-40

13. Akbari M, Abachizadeh K, Khayamzadeh M, Tabatabaee M, Esnaashari F, Motlagh A (2008) Iran cancer report. Cancer Research Center, Shahid Beheshti University of Medical Sciences, Tehran, Qom: Darolfekr

14. Razi S (2015) Epidemiology of prevalent cancer among Iranian women and its incidence trends from 2003-2009 in Iran.

15. Kelsey JL, Berkowitz GS (1988) Breast cancer epidemiology. Cancer research 48 (20):5615-5623

16. Hajian K (2013) Association of obesity and central obesity with breast cancer risk in pre and postmenopausal women.

17. AMINI SN, Shamshirgaran S, GHAVAM NM, Setayesh Y (2005) The effect of active and passive smoking associated with breast cancer.

18. Hajizadeh N, Pourhoseingholi M, Emadedin M, Baghestani A, Fazeli Z (2015) Incidence rate of breast cancer in iranian women, trend analysis from 2003 to 2009. Int J Pharma Biomed Sci 4 (3): 107-112 19. Yaghmaei S, Bani Hashemi G, Ghorbani R (2008) Survival rate following treatment of primary breast cancer in Semnan, Iran (1991-2002). Koomesh:111-116

20. Huo D, Adebamowo C, Ogundiran T, Akang E, Campbell O, Adenipekun A, Cummings S, Fackenthal J, Ademuyiwa F, Ahsan H (2008) Parity and breastfeeding are protective against breast cancer in Nigerian women. British journal of cancer 98 (5):992

21. Motamed N, Hadi N, Talei A (2004) A Survey on risk factors of breast cancer in women over 35 years of age (Shiraz-2000). 
22. Naieni KH, Ardalan A, Mahmoodi M, Motevalian A, Yahyapoor Y, Yazdizadeh B (2007) Risk factors of breast cancer in north of Iran: a case-control in Mazandaran Province. Asian Pacific Journal of Cancer Prevention 8 (3):395

23. Peterson NB, Huang Y, Newcomb PA, Titus-Ernstoff L, Trentham-Dietz A, Anic G, Egan KM (2008) Childbearing recency and modifiers of premenopausal breast cancer risk. Cancer Epidemiology and Prevention Biomarkers 17 (11):3284-3287

24. Ebrahimi M, Vahdaninia M, Montazeri A (2002) Risk factors for breast cancer in Iran: a case-control study. Breast cancer research : BCR 4 (5):R10. doi:10.1186/bcr454

25. Pesaran Z, Rezaei A, Tavakoli Kia R, Siydat Ah (2003) Evaluation of breast cancer risk factors for using in hormone replacement therapy of corticosteroid- treated post-menopausal women \% J Journal of Shahrekord Uuniversity of Medical Sciences. J Shahrekord Univ Med Sci 5 (2):70-75

26. Montazeri A, Jarvandi S, Ebrahimi M, Haghighat S, Ansari M (2004) The role of depression in the development of breast cancer: analysis of registry data from a single institute. Asian Pacific journal of cancer prevention : APJCP 5 (3):316-319

27. Yavari P, Mosavizadeh M, Sadrolhefaz iB, Khodabakhshi R, Madani H, Mehrabi Y (2006) Reproductive Characteristics and the Risk of Breast Cancer: A Case-Control Study. Iranian Journal of Epidemiology 1 (3):11-19

28. Mahouri K, Dehghani Zahedani M, Zare S (2007) Breast cancer risk factors in south of Islamic Republic of Iran: a case-control study. Eastern Mediterranean health journal = La revue de sante de la Mediterranee orientale = al-Majallah al-sihhiyah li-sharq al-mutawassit 13 (6):1265-1273

29. Naieni KH, Ardalan A, Mahmoodi M, Motevalian A, Yahyapoor Y, Yazdizadeh B (2007) Risk factors of breast cancer in north of Iran: a case-control in Mazandaran Province. Asian Pacific journal of cancer prevention : APJCP 8 (3):395-398

30. Lotfi M, Shobairi SCSJAMI (2008) Breast cancer risk factors in an urban area of Yazd City-Iran, 2006. Acta Med Iran 46 (3):253-257 
31. Kazemi M, Salehi Z, Chakosari RJ (2009) TP53 codon 72 polymorphism and breast cancer in northern Iran. Oncology research 18 (1):25-30

32. Ghiasvand R, Maram ES, Tahmasebi S, Tabatabaee SH (2010) Risk factors for breast cancer among young women in southern Iran. International journal of cancer 129 (6):1443-1449. doi:10.1002/ijc.25748

33. Hajian-Tilaki KO, Kaveh-Ahangar T (2011) Reproductive factors associated with breast cancer risk in northern Iran. Medical oncology (Northwood, London, England) 28 (2):441-446. doi:10.1007/s12032-0109498-z

34. Hajian-Tilaki K, Kaveh-Ahangar T, Hajian-Tilaki E (2011) Is educational level associated with breast cancer risk in Iranian women? Breast cancer (Tokyo, Japan) 19 (1):64-70. doi:10.1007/s12282-011-02736

35. Motie MR, Besharat S, Torkjazi R, Shojaa M, Besharat M, Keshtkar A, Roshandel G, Besharat S, Fateme AA (2011) Modifiable Risk of Breast Cancer in Northeast Iran: Hope for the Future. A CaseControl Study. Breast care (Basel, Switzerland) 6 (6):453-456. doi:10.1159/000335203

36. Ghiasvand R, Bahmanyar S, Zendehdel K, Tahmasebi S, Talei A, Adami H-O, Cnattingius S (2012) Postmenopausal breast cancer in Iran; risk factors and their population attributable fractions. BMC Cancer 12 (1):414. doi:10.1186/1471-2407-12-414

37. Sigaroodi A, Nadji SA, Naghshvar F, Nategh R, Emami H, Velayati AA (2012) Human papillomavirus is associated with breast cancer in the north part of Iran. TheScientificWorldJournal 2012:837191. doi:10.1100/2012/837191

38. Ahmadinejad N, Movahedinia S, Movahedinia S, Holakouie Naieni K, Nedjat S (2013) Distribution of breast density in Iranian women and its association with breast cancer risk factors. Iranian Red Crescent medical journal 15 (12):e16615. doi:10.5812/ircmj.16615

39. Kaviani A, Neishaboury M, Mohammadzadeh N, Ansari-Damavandi M, Jamei K (2013) Effects of obesity on presentation of breast cancer, lymph node metastasis and patient survival: a retrospective review. Asian Pacific journal of cancer prevention : APJCP 14 (4):2225-2229. doi:10.7314/apjcp.2013.14.4.2225 
40. Pourzand A, Farajkhah H, Azhough R, Fakhree MBAJLSJ (2013) Breast cancer risk factors among women without family history in North West of Iran. Life Science Journal 10 (7s)

41. Zare N, Haem E, Lankarani KB, Heydari ST, Barooti E (2013) Breast cancer risk factors in a defined population: weighted logistic regression approach for rare events. Journal of breast cancer 16 (2):214-219. doi:10.4048/jbc.2013.16.2.214

42. Bidgoli SA, Azarshab H (2014) Role of vitamin D deficiency and lack of sun exposure in the incidence of premenopausal breast cancer: a case control study in Sabzevar, Iran. Asian Pacific journal of cancer prevention : APJCP 15 (8):3391-3396. doi:10.7314/apjcp.2014.15.8.3391

43. Hosseinzadeh M, Eivazi Ziaei J, Mahdavi N, Aghajari P, Vahidi M, Fateh A, Asghari E (2014) Risk factors for breast cancer in Iranian women: a hospital-based case-control study in tabriz, iran. Journal of breast cancer 17 (3):236-243. doi:10.4048/jbc.2014.17.3.236

44. Mobarakeh ZS, Mirzaei K, Hatmi N, Ebrahimi M, Dabiran S, Sotoudeh G (2014) Dietary habits contributing to breast cancer risk among Iranian women. Asian Pacific journal of cancer prevention : APJCP 15 (21):9543-9547. doi:10.7314/apjcp.2014.15.21.9543

45. Sepandi M, Akrami M, Tabatabaee H, Rajaeefard A, Tahmasebi S, Angali KA, Rezaianzadeh A, Talei A (2014) Breast cancer risk factors in women participating in a breast screening program: a study on 11,850 Iranian females. Asian Pacific journal of cancer prevention : APJCP 15 (19):8499-8502. doi:10.7314/apjcp.2014.15.19.8499

46. Tazhibi M, Dehghani M, Babazadeh S, Makkarian F, Tabatabaeian M, Sadeghi M, Rezaei P, Faghihi M (2014) Hormonal and reproductive risk factors associated with breast cancer in Isfahan patients. Journal of education and health promotion 3:69. doi:10.4103/2277-9531.134818

47. Salarabadi A, Bidgoli SA, Madani SH (2015) Roles of Kermanshahi Oil, Animal Fat, Dietary and NonDietary Vitamin D and other Nutrients in Increased Risk of Premenopausal Breast Cancer: A Case Control Study in Kermanshah, Iran. Asian Pacific journal of cancer prevention : APJCP 16 (17):7473-7478. doi:10.7314/apjcp.2015.16.17.7473 
48. Tajaddini A, Pourzand A, Sanaat Z, Pirouzpanah S (2015) Dietary resistant starch contained foods and breast cancer risk: a case-control study in northwest of Iran. Asian Pacific journal of cancer prevention : APJCP 16 (10):4185-4192. doi:10.7314/apjcp.2015.16.10.4185

49. Veisy A, Lotfinejad S, Salehi K, Zhian F (2015) Risk of breast cancer in relation to reproductive factors in North-West of Iran, 2013-2014. Asian Pacific journal of cancer prevention : APJCP 16 (2):451-455. doi:10.7314/apjcp.2015.16.2.451

50. Ahmadnia Z, Joukar F, Hasavari F, Roushan ZA, Khalili M (2016) Dietary Patterns and Risk of Breast Cancer in Women in Guilan Province, Iran. Asian Pacific journal of cancer prevention : APJCP 17 (4):20352040. doi:10.7314/apjcp.2016.17.4.2035

51. Jafari-Mehdiabad F, Savabi-Esfahani M, Mokaryan F, Kazemi A (2016) Relationship between breastfeeding factors and breast cancer in women referred to Seyed Al-Shohada Hospital in Isfahan, Iran. Iranian journal of nursing and midwifery research 21 (6):622-627. doi:10.4103/1735-9066.197670

52. Jafarinia B, Bahadorzai M, Delpisheh A, Sayehmiri K, Tavakoli M (2016) Risk factors of breast cancer in Dezful city of Iran: a case-control study. Tehran University Medical Journal 74 (2):135-139

53. Montazeri V, Jafarpour Sadegh F, Hosseinpour S, Mirzaei H, Akbari E, Ehsani M, Akbari S, Asadi N, Mahmoudinezhad M, Mirtaheri E, Sanaat Z, Pirouzpanah S (2016) Reproductive Risk Factors of Breast Cancer among Women in Tehran and Northwest of Iran: A Case-Control Study Iranian Journal of Epidemiology $12(1): 1-9$

54. Dehghan Z, Sadeghi S, Tabatabaeian H, Ghaedi K, Azadeh M, Fazilati M, Bagheri F (2017) ESR1 single nucleotide polymorphism rs1062577 (c.*3804T>A) alters the susceptibility of breast cancer risk in Iranian population. Gene 611:9-14. doi:10.1016/j.gene.2017.02.016

55. Dianatinasab M, Fararouei M, Mohammadianpanah M, Zare-Bandamiri M, Rezaianzadeh A (2017) Hair Coloring, Stress, and Smoking Increase the Risk of Breast Cancer: A Case-Control Study. Clinical breast cancer 17 (8):650-659. doi:10.1016/j.clbc.2017.04.012

56. Dianatinasab M, Mohammadianpanah M, Daneshi N, Zare-Bandamiri M, Rezaeianzadeh A, Fararouei M (2017) Socioeconomic Factors, Health Behavior, and Late-Stage Diagnosis of Breast Cancer: 
Considering the Impact of Delay in Diagnosis. Clinical breast cancer 18 (3):239-245. doi:10.1016/j.clbc.2017.09.005

57. Mirfarhadi N, Ghanbari A, Khalili M, Rahimi A (2017) Predictive Factors for Diagnosis and Treatment Delay in Iranian Women with Breast Cancer. Nursing and Midwifery Studies 6 (2):-. doi:10.5812/nmsjournal.27452

58. Vahid F, Hatami M, Sadeghi M, Ameri F, Faghfoori Z, Davoodi SH (2017) The association between the Index of Nutritional Quality (INQ) and breast cancer and the evaluation of nutrient intake of breast cancer patients: A case-control study. Nutrition (Burbank, Los Angeles County, Calif) 45:11-16. doi:10.1016/j.nut.2017.06.011

59. Fararouei M, Iqbal A, Rezaian S, Gheibi Z, Dianatinasab A, Shakarami S, Dianatinasab M (2018) Dietary Habits and Physical Activity are Associated With the Risk of Breast Cancer Among Young Iranian Women: A Case-control Study on 1010 Premenopausal Women. Clinical breast cancer 19 (1):e127-e134. doi:10.1016/j.clbc.2018.10.011

60. Pouladi N, Dehghan R, Hosseinpour Feizi M, Dastmalchi N (2018) Association of P53 (+ 16ins-Arg) Haplotype with the Increased Susceptibility to Breast Cancer in Iranian-Azeri Women. Journal of Kerman University of Medical Sciences 25 (1):9-17

61. Vahid F, Shivappa N, Hatami M, Sadeghi M, Ameri F, Jamshidi Naeini Y, Hebert JR, Davoodi SH (2018) Association between Dietary Inflammatory Index (DII) and Risk of Breast Cancer: a Case-Control Study. Asian Pacific journal of cancer prevention : APJCP 19 (5):1215-1221. doi:10.22034/apjcp.2018.19.5.1215

62. Marzbani B, Nazari J, Najafi F, Marzbani B, Shahabadi S, Amini M, Moradinazar M, Pasdar Y, Shakiba E, Amini S (2019) Dietary patterns, nutrition, and risk of breast cancer: a case-control study in the west of Iran. Epidemiology and health 41:e2019003. doi:10.4178/epih.e2019003

63. Modesti PA, Reboldi G, Cappuccio FP, Agyemang C, Remuzzi G, Rapi S, Perruolo E, Parati G (2016) Panethnic Differences in Blood Pressure in Europe: A Systematic Review and Meta-Analysis. PloS one 11 (1):e0147601. doi:10.1371/journal.pone.0147601 
64. Pharoah PD, Day NE, Duffy S, Easton DF, Ponder BA (1997) Family history and the risk of breast cancer: a systematic review and meta-analysis. International journal of cancer 71 (5):800-809. doi:10.1002/(sici)1097-0215(19970529)71:5<800::aid-ijc18>3.0.co;2-b

65. Brewer HR, Jones ME, Schoemaker MJ, Ashworth A, Swerdlow AJ (2017) Family history and risk of breast cancer: an analysis accounting for family structure. Breast cancer research and treatment 165 (1):193200. doi:10.1007/s10549-017-4325-2

66. Nindrea RD, Aryandono T, Lazuardi L (2017) Breast Cancer Risk From Modifiable and NonModifiable Risk Factors among Women in Southeast Asia: A Meta-Analysis. Asian Pacific journal of cancer prevention : APJCP 18 (12):3201-3206. doi:10.22034/apjcp.2017.18.12.3201

67. Tao P, Hu YY, Huang Y, Li JY (2011) [Risk factors of breast cancer in Asian women: a meta-analysis]. Zhonghua liu xing bing xue za zhi = Zhonghua liuxingbingxue zazhi 32 (2):164-169

68. Germain D (2011) Estrogen carcinogenesis in breast cancer. Endocrinology and metabolism clinics of North America 40 (3):473-484, vii. doi:10.1016/j.ecl.2011.05.009

69. Yager JD, Davidson NE (2006) Estrogen carcinogenesis in breast cancer. The New England journal of medicine 354 (3):270-282. doi:10.1056/NEJMra050776

70. Anothaisintawee T, Wiratkapun C, Lerdsitthichai P, Kasamesup V, Wongwaisayawan S, Srinakarin J, Hirunpat S, Woodtichartpreecha P, Boonlikit S, Teerawattananon Y, Thakkinstian A (2013) Risk factors of breast cancer: a systematic review and meta-analysis. Asia-Pacific journal of public health 25 (5):368387. doi:10.1177/1010539513488795

71. Chen C-L, Weiss NS, Newcomb P, Barlow W, White E (2002) Hormone Replacement Therapy in Relation to Breast Cancer. JAMA 287 (6):734-741. doi:10.1001/jama.287.6.734 \%J JAMA

72. Sillero-Arenas M, Delgado-Rodriguez M, Rodigues-Canteras R, Bueno-Cavanillas A, Galvez-Vargas R (1992) Menopausal hormone replacement therapy and breast cancer: a meta-analysis. Obstet Gynecol 79 (2286-94) 
73. Bae JM, Kim EH (2015) Hormone Replacement Therapy and Risk of Breast Cancer in Korean Women: A Quantitative Systematic Review. Journal of preventive medicine and public health = Yebang Uihakhoe chi 48 (5):225-230. doi:10.3961/jpmph.15.046

74. Petticrew M, Fraser JM, Regan MF (1999) Adverse life-events and risk of breast cancer: A metaanalysis. 4 (1):1-17. doi:10.1348/135910799168434

75. Duijts SF, Zeegers MP, Borne BV (2003) The association between stressful life events and breast cancer risk: a meta-analysis. International journal of cancer 107 (6):1023-1029. doi:10.1002/ijc.11504

76. Santos MC, Horta BL, Amaral JJ, Fernandes PF, Galvao CM, Fernandes AF (2009) Association between stress and breast cancer in women: a meta-analysis. Cadernos de saude publica 25 Suppl 3:S453463

77. Lin Y, Wang C, Zhong Y, Huang X, Peng L, Shan G, Wang K, Sun Q (2013) Striking life events associated with primary breast cancer susceptibility in women: a meta-analysis study. Journal of experimental \& clinical cancer research : CR 32 (1):53. doi:10.1186/1756-9966-32-53

78. Chen C, Huang YB, Liu XO, Gao Y, Dai HJ, Song FJ, Li WQ, Wang J, Yan Y, Wang PS, Wang YG, Chen KX (2014) Active and passive smoking with breast cancer risk for Chinese females: a systematic review and meta-analysis. Chinese journal of cancer 33 (6):306-316. doi:10.5732/cjc.013.10248

79. Chen Z, Shao J, Gao X, Li X (2015) Effect of passive smoking on female breast cancer in China: a meta-analysis. Asia-Pacific journal of public health 27 (2):Np58-64. doi:10.1177/1010539513481493 80. Johnson KC, Miller AB, Collishaw NE, Palmer JR, Hammond SK, Salmon AG, Cantor KP, Miller MD, Boyd NF, Millar J, Turcotte F (2011) Active smoking and secondhand smoke increase breast cancer risk: the report of the Canadian Expert Panel on Tobacco Smoke and Breast Cancer Risk (2009). Tobacco control 20 (1):e2. doi:10.1136/tc.2010.035931

81. Macacu A, Autier P, Boniol M, Boyle P (2015) Active and passive smoking and risk of breast cancer: a meta-analysis. Breast cancer research and treatment 154 (2):213-224. doi:10.1007/s10549-015-3628-4 
82. Albrektsen G, Heuch I, Hansen S, Kvale G (2005) Breast cancer risk by age at birth, time since birth and time intervals between births: exploring interaction effects. British journal of cancer 92 (1):167-175. doi:10.1038/sj.bjc.6602302

83. Ramon JM, Escriba JM, Casas I, Benet J, Iglesias C, Gavalda L, Torras G, Oromi J (1996) Age at first full-term pregnancy, lactation and parity and risk of breast cancer: a case-control study in Spain. European journal of epidemiology 12 (5):449-453

84. Balekouzou A, Yin P, Pamatika CM, Bekolo CE, Nambei SW, Djeintote M, Kota K, Mossoro-Kpinde CD, Shu C, Yin M, Fu Z, Qing T, Yan M, Zhang J, Chen S, Li H, Xu Z, Koffi B (2017) Reproductive risk factors associated with breast cancer in women in Bangui: a case-control study. BMC women's health 17 (1):14. doi:10.1186/s12905-017-0368-0

85. Nelson HD, Zakher B, Cantor A, Fu R, Griffin J, O'Meara ES, Buist DS, Kerlikowske K, van Ravesteyn NT, Trentham-Dietz A, Mandelblatt JS, Miglioretti DL (2012) Risk factors for breast cancer for women aged 40 to 49 years: a systematic review and meta-analysis. Annals of internal medicine 156 (9):635-648. doi:10.7326/0003-4819-156-9-201205010-00006

86. Remennick LI (1990) Induced abortion as cancer risk factor: a review of epidemiological evidence. Journal of epidemiology and community health 44 (4):259-264. doi:10.1136/jech.44.4.259

87. Brind J, Chinchilli VM, Severs WB, Summy-Long J (1996) Induced abortion as an independent risk factor for breast cancer: a comprehensive review and meta-analysis. Journal of epidemiology and community health 50 (5):481-496. doi:10.1136/jech.50.5.481

88. Huang Y, Zhang X, Li W, Song F, Dai H, Wang J, Gao Y, Liu X, Chen C, Yan Y, Wang Y, Chen K (2014) A meta-analysis of the association between induced abortion and breast cancer risk among Chinese females. Cancer causes \& control : CCC 25 (2):227-236. doi:10.1007/s10552-013-0325-7

89. Guo J, Huang Y, Yang L, Xie Z, Song S, Yin J, Kuang L, Qin W (2015) Association between abortion and breast cancer: an updated systematic review and meta-analysis based on prospective studies. Cancer causes \& control : CCC 26 (6):811-819. doi:10.1007/s10552-015-0536-1 
90. Michels KB, Hsieh CC, Trichopoulos D, Willett WC (1995) Abortion and breast cancer risk in seven countries. Cancer causes \& control : CCC 6 (1):75-82

91. Landa MC, Frago N, Tres A (1994) Diet and the risk of breast cancer in Spain. European journal of cancer prevention : the official journal of the European Cancer Prevention Organisation (ECP) 3 (4):313320

92. Lubin JH, Burns PE, Blot WJ, Ziegler RG, Lees AW, Fraumeni Jr. JF (1981) Dietary factors and breast cancer risk. 28 (6):685-689. doi:10.1002/ijc.2910280605

93. Potischman N, Coates RJ, Swanson CA, Carroll RJ, Daling JR, Brogan DR, Gammon MD, Midthune D, Curtin J, Brinton LA (2002) Increased risk of early-stage breast cancer related to consumption of sweet foods among women less than age 45 in the United States. Cancer causes \& control : CCC 13 (10):937-946 94. Tavani A, Giordano L, Gallus S, Talamini R, Franceschi S, Giacosa A, Montella M, La Vecchia C (2005) Consumption of sweet foods and breast cancer risk in Italy. Annals of Oncology 17 (2):341-345. doi:10.1093/annonc/mdj051\%J Annals of Oncology

95. Augustin LS, Dal Maso L, La Vecchia C, Parpinel M, Negri E, Vaccarella S, Kendall CW, Jenkins DJ, Francesch S (2001) Dietary glycemic index and glycemic load, and breast cancer risk: a case-control study. Annals of oncology : official journal of the European Society for Medical Oncology 12 (11):1533-1538. doi:10.1023/a:1013176129380

96. Dobson R (2005) Sweet foods increase breast cancer risk. BMJ 331 (7525):1102-1102

97. He XF, Su J, Zhang Y, Huang X, Liu Y, Ding DP, Wang W, Arparkorn K (2011) Association between the p53 polymorphisms and breast cancer risk: meta-analysis based on case-control study. Breast cancer research and treatment 130 (2):517-529. doi:10.1007/s10549-011-1583-2

98. Hou J, Jiang Y, Tang W, Jia S (2013) p53 codon 72 polymorphism and breast cancer risk: A metaanalysis. Experimental and therapeutic medicine 5 (5):1397-1402. doi:10.3892/etm.2013.1019

99. Ma Y, Yang J, Liu Z, Zhang P, Yang Z, Wang Y, Qin H (2011) No significant association between the TP53 codon 72 polymorphism and breast cancer risk: a meta-analysis of 21 studies involving 24,063 subjects. Breast cancer research and treatment 125 (1):201-205. doi:10.1007/s10549-010-0920-1 
100. Marshall WA, Tanner JM (1969) Variations in pattern of pubertal changes in girls. Archives of disease in childhood 44 (235):291-303. doi:10.1136/adc.44.235.291

101. Li H, Sun X, Miller E, Wang Q, Tao P, Liu L, Zhao Y, Wang M, Qi Y, Li J (2017) BMI, reproductive factors, and breast cancer molecular subtypes: A case-control study and meta-analysis. Journal of epidemiology 27 (4):143-151. doi:10.1016/j.je.2016.05.002

102. Cancer CGoHFiB (2012) Menarche, menopause, and breast cancer risk: individual participant metaanalysis, including 118964 women with breast cancer from 117 epidemiological studies. The Lancet Oncology 13 (11):1141-1151. doi:10.1016/s1470-2045(12)70425-4

103. Bernier MO, Plu-Bureau G, Bossard N, Ayzac L, Thalabard JC (2000) Breastfeeding and risk of breast cancer: a metaanalysis of published studies. Human reproduction update 6 (4):374-386. doi:10.1093/humupd/6.4.374

104. Islami F, Liu Y, Jemal A, Zhou J, Weiderpass E, Colditz G, Boffetta P, Weiss M (2015) Breastfeeding and breast cancer risk by receptor status--a systematic review and meta-analysis. Annals of oncology : official journal of the European Society for Medical Oncology 26 (12):2398-2407. doi:10.1093/annonc/mdv379

105. Unar-Munguia M, Torres-Mejia G, Colchero MA, Gonzalez de Cosio T (2017) Breastfeeding Mode and Risk of Breast Cancer: A Dose-Response Meta-Analysis. Journal of human lactation : official journal of International Lactation Consultant Association 33 (2):422-434. doi:10.1177/0890334416683676

106. Zhou Y, Chen J, Li Q, Huang W, Lan H, Jiang H (2015) Association between breastfeeding and breast cancer risk: evidence from a meta-analysis. Breastfeeding medicine : the official journal of the Academy of Breastfeeding Medicine 10 (3):175-182. doi:10.1089/bfm.2014.0141

107. Breast cancer and breastfeeding: collaborative reanalysis of individual data from 47 epidemiological studies in 30 countries, including 50302 women with breast cancer and 96973 women without the disease (2002). Lancet (London, England) 360 (9328):187-195. doi:10.1016/s0140-6736(02)09454-0

108. Fund WCR, Research AIfC (2007) Food, nutrition, physical activity, and the prevention of cancer: a global perspective, vol 1. Amer Inst for Cancer Research, 
109. Kushi LH, Doyle C, McCullough M, Rock CL, Demark-Wahnefried W, Bandera EV, Gapstur S, Patel AV, Andrews K, Gansler T (2012) American Cancer Society Guidelines on nutrition and physical activity for cancer prevention: reducing the risk of cancer with healthy food choices and physical activity. CA: a cancer journal for clinicians 62 (1):30-67. doi:10.3322/caac.20140

110. McTiernan A, Ulrich C, Slate S, Potter J (1998) Physical activity and cancer etiology: associations and mechanisms. Cancer causes \& control : CCC 9 (5):487-509

111. Aune D, Chan DS, Greenwood DC, Vieira AR, Rosenblatt DA, Vieira R, Norat T (2012) Dietary fiber and breast cancer risk: a systematic review and meta-analysis of prospective studies. Annals of oncology : official journal of the European Society for Medical Oncology 23 (6):1394-1402. doi:10.1093/annonc/mdr589

112. Liu X, Lv K (2013) Cruciferous vegetables intake is inversely associated with risk of breast cancer: a meta-analysis. Breast (Edinburgh, Scotland) 22 (3):309-313. doi:10.1016/j.breast.2012.07.013

113. Woo HD, Park S, Oh K, Kim HJ, Shin HR, Moon HK, Kim J (2014) Diet and cancer risk in the Korean population: a meta- analysis. Asian Pacific journal of cancer prevention : APJCP 15 (19):8509-8519. doi:10.7314/apjcp.2014.15.19.8509

114. Smith-Warner SA, Spiegelman D, Yaun SS, Adami HO, Beeson WL, van den Brandt PA, Folsom AR, Fraser GE, Freudenheim JL, Goldbohm RA, Graham S, Miller AB, Potter JD, Rohan TE, Speizer FE, Toniolo P, Willett WC, Wolk A, Zeleniuch-Jacquotte A, Hunter DJ (2001) Intake of fruits and vegetables and risk of breast cancer: a pooled analysis of cohort studies. Jama 285 (6):769-776. doi:10.1001/jama.285.6.769

115. van Gils CH, Peeters PH, Bueno-de-Mesquita HB, Boshuizen HC, Lahmann PH, Clavel-Chapelon F, Thiebaut A, Kesse E, Sieri S, Palli D, Tumino R, Panico S, Vineis P, Gonzalez CA, Ardanaz E, Sanchez MJ, Amiano P, Navarro C, Quiros JR, Key TJ, Allen N, Khaw KT, Bingham SA, Psaltopoulou T, Koliva M, Trichopoulou A, Nagel G, Linseisen J, Boeing H, Berglund G, Wirfalt E, Hallmans G, Lenner P, Overvad K, Tjonneland A, Olsen A, Lund E, Engeset D, Alsaker E, Norat T, Kaaks R, Slimani N, Riboli E 
(2005) Consumption of vegetables and fruits and risk of breast cancer. Jama 293 (2):183-193. doi:10.1001/jama.293.2.183

116. Aune D, Chan DS, Vieira AR, Rosenblatt DA, Vieira R, Greenwood DC, Norat T (2012) Fruits, vegetables and breast cancer risk: a systematic review and meta-analysis of prospective studies. Breast cancer research and treatment 134 (2):479-493. doi:10.1007/s10549-012-2118-1

117. Jung S, Spiegelman D, Baglietto L, Bernstein L, Boggs DA, van den Brandt PA, Buring JE, Cerhan JR, Gaudet MM, Giles GG, Goodman G, Hakansson N, Hankinson SE, Helzlsouer K, Horn-Ross PL, Inoue M, Krogh V, Lof M, McCullough ML, Miller AB, Neuhouser ML, Palmer JR, Park Y, Robien K, Rohan TE, Scarmo S, Schairer C, Schouten LJ, Shikany JM, Sieri S, Tsugane S, Visvanathan K, Weiderpass E, Willett WC, Wolk A, Zeleniuch-Jacquotte A, Zhang SM, Zhang X, Ziegler RG, Smith-Warner SA (2013) Fruit and vegetable intake and risk of breast cancer by hormone receptor status. Journal of the National Cancer Institute 105 (3):219-236. doi:10.1093/jnci/djs635 